\title{
QUEEN'S
UNIVERSITY
BELFAST
}

\section{Preparation, modification and development of Ni-based catalysts for catalytic reforming of tar produced from biomass gasification}

Zhang, Z., Liu, L., Shen, B., \& Wu, C. (2018). Preparation, modification and development of Ni-based catalysts for catalytic reforming of tar produced from biomass gasification. Renewable and Sustainable Energy Reviews, 94, 1086-1109. https://doi.org/10.1016/j.rser.2018.07.010

\section{Published in:}

Renewable and Sustainable Energy Reviews

\section{Document Version:}

Peer reviewed version

Queen's University Belfast - Research Portal:

Link to publication record in Queen's University Belfast Research Portal

\section{Publisher rights}

Copyright 2018 Elsevier Ltd.

This manuscript is distributed under a Creative Commons Attribution-NonCommercial-NoDerivs License

(https://creativecommons.org/licenses/by-nc-nd/4.0/), which permits distribution and reproduction for non-commercial purposes, provided the author and source are cited.

\section{General rights}

Copyright for the publications made accessible via the Queen's University Belfast Research Portal is retained by the author(s) and / or other copyright owners and it is a condition of accessing these publications that users recognise and abide by the legal requirements associated with these rights.

\footnotetext{
Take down policy

The Research Portal is Queen's institutional repository that provides access to Queen's research output. Every effort has been made to ensure that content in the Research Portal does not infringe any person's rights, or applicable UK laws. If you discover content in the Research Portal that you believe breaches copyright or violates any law, please contact openaccess@qub.ac.uk.
} 


\title{
Preparation, modification and development of Ni-based catalysts for catalytic reforming of tar produced from biomass gasification
}

\author{
Zhikun Zhang ${ }^{\mathrm{a}}$, Lina Liu ${ }^{\mathrm{b},{ }^{*}, \text { Boxiong Shen }}{ }^{\mathrm{a},}{ }^{*}$, Chunfei Wu, c, ${ }^{\mathrm{a}}$
}

a School of Energy and Environmental Engineering, Hebei University of Technology, Tianjin 300401, China

${ }^{b}$ Energy and Environment International Centre, School of Energy and Power Engineering, Beihang University, Beijing 100191, China

' School of Engineering and Computer Science, University of Hull, Hull HU6 7RX, United Kingdom

* Corresponding authors. E-mail address: liuln1993@buaa.edu.cn (Liu L.); shenbx@nankai.edu.cn (Shen

B.);c.wu@hull.ac.uk (Wu C.) 


\begin{abstract}
Biomass gasification is one of the most promising technologies to convert renewable biomass feedstock to useful energy and chemicals for decarbonizing the current industrial activities. However, complex tar compounds are formed in the produced syngas. The presence of tar in syngas is undesirable due to a series problems caused, such as the decrease of overall efficiency and the clogging and contamination of downstream equipment. Until now, catalytic steam reforming has been widely studied for the efficient removal of tar. Previous review articles have focused on the catalytic reforming of tar by categorizing various catalysts as basic catalysts, nickel-based catalysts, non-nickel based catalysts, alkali metal catalysts, zeolite catalysts, and carbon-supported catalysts, etc. Ni-based steam-reforming catalysts have attracted much attention due to their high activity for tar reduction, low-cost and easy regeneration. However, the deactivation caused by the coke deposition and metal sintering remains the greatest challenge for the deployment of the technology. Therefore, modified Ni-based catalysts are now most frequently used for catalytic reforming of tar. At present, few review articles reported the modification of Ni-based catalysts for catalytic reforming of tar compounds. Based on this, the preparation, modification and development methods of Ni-based catalysts for catalytic reforming of tar are reviewed in this paper, aiming at promoting the catalytic performance of conventional Ni-based catalysts, in terms of high catalytic activity, long-term stability and better selectivity towards low molecular weight compounds.
\end{abstract}

Key Words: Biomass gasification; Tar; Steam reforming; Ni-based catalyst; catalytic performance. 


\section{Contents}

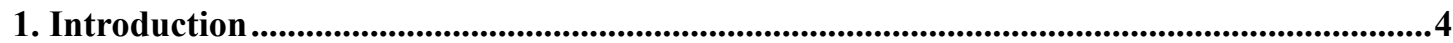

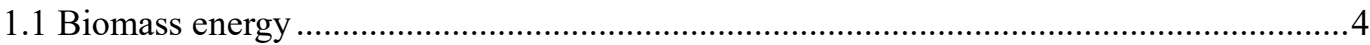

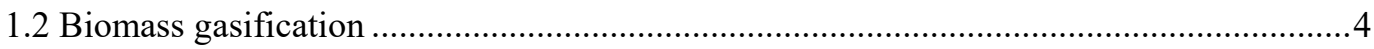

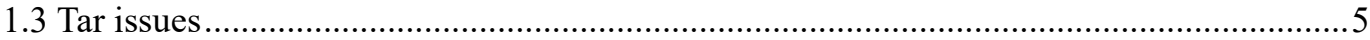

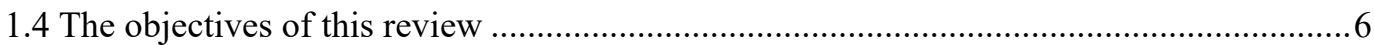

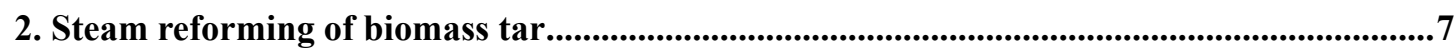

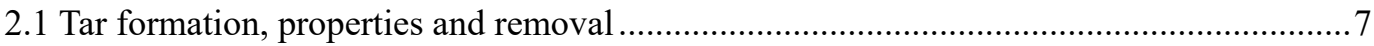

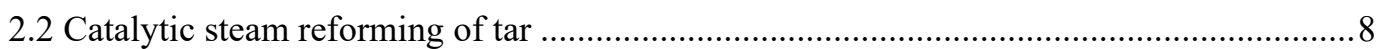

3. Ni-based catalysts for Catalytic steam reforming of tar ...........................................................10

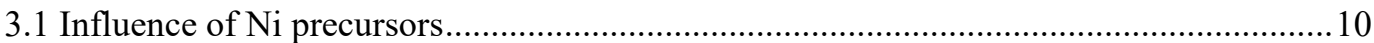

3.2 Influences of preparation and pre-treated methods ........................................................... 11

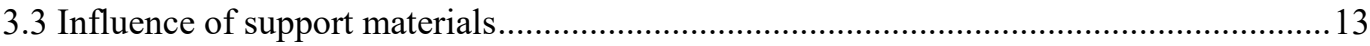

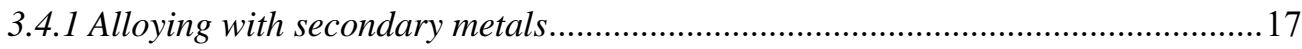

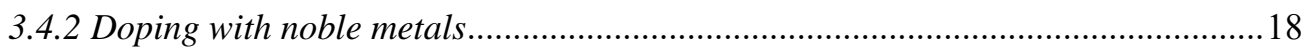

3.4.3 Doping with rare earth oxides (REOs).............................................................. 19

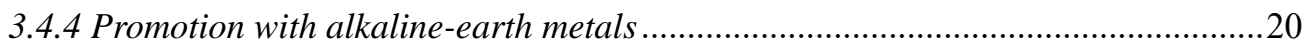

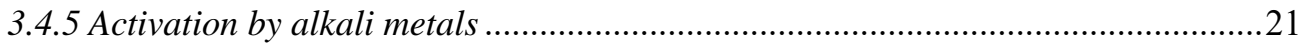

4. Concluding remarks and further prospects.................................................................................23

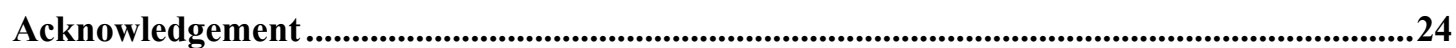

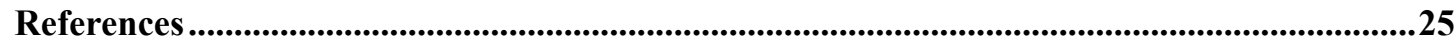




\section{Introduction}

\subsection{Biomass energy}

Renewable energy sources (RES), including biomass, hydropower, geothermal, solar, wind and marine energies, provide 14\% of the total world energy demand [1]. Among the RES, biomass energy derived from agricultural, forest and municipal solid wastes is considered as one of the most promising alternatives [2], due to its abundant resources and neutral property in $\mathrm{CO}_{2}$ circulation. According to the global renewable energy scenario by 2040 (Table 1), the share of biomass is much more than other RES, contributing more than $50 \%$ of the total RES [1]. In addition, bioenergy has various social and environmental benefits, such as reducing the emission of greenhouse gases (GHGs), $\mathrm{NO}_{\mathrm{x}}$ and $\mathrm{SO}_{\mathrm{x}}$, lowering the risk of soil and water acidification, increasing the value of agricultural output, and decreasing the dependence on fossil energy [3]. The increasing consumption and high price of fossil energy (coal, oil and natural gas), together with the rising threat of global warming, make the utilization of biomass more and more attractive [4]. Biomass energy has been the fourth largest energy source since 1990, and occupies $13 \%$ of the world's total primary energy consumption (55 EJ per year) (Figure 1). Specifically, a much larger proportion of $33 \%$ is obtained for biomass in developing countries, containing $75 \%$ of world's population [5], because agriculture is a major industry in developing countries [6]. In addition, it is estimated in the renewable intensive global energy scenario (RIGES) in 1992 that, by 2050, biomass could provide half of the world's total primary energy consumption (400 EJ per year), and almost $60 \%$ of electricity demand in the world could be supplied by renewables among which biomass is an important feedstock [7].

Biomass is mainly composed of cellulose, hemicellulose, lignin and minerals [8]. Biomass can be utilized to produce heat, electricity and various chemical feedstock by various methods including thermal-chemical processes and bio-chemical processes. The thermal-chemical processing of biomass includes direct combustion, pyrolysis and gasification [9]. Among them, biomass gasification is one of the most economical and efficient methods to convert biomass into energy species. $[10,11]$.

$<$ Table 1>

$<$ Figure 1 $>$

\subsection{Biomass gasification}

Gasification of biomass is a thermal-chemical process where carbonaceous materials can be converted to combustive gas fuel in the presence of limited amount of oxidizing agents (e.g. $\mathrm{O}_{2}$, air, steam, $\left.\mathrm{CO}_{2}\right)$ at relative high temperatures $\left(>700{ }^{\circ} \mathrm{C}\right) .[10,11]$ On one hand, the processing of biomass wastes is beneficial to the reduction of landfill disposal and global warming [12]. On the other hand, the obtained syngas from biomass gasification can be used as secondary raw feedstock to produce methanol, dimethylether (DME), ethanol, Fischer-Tropsch fuels, as well as generating heat and electricity [13]. Meanwhile, some undesirable by-products, such as tar and solid particulates, are also generated [14]. The main processes and reactions of biomass gasification are shown in Figure 2. It is indicated that biomass gasification can be generally classified into four steps: drying, pyrolysis, oxidation, and gasification [15]. The exceeded moisture should be evaporated firstly upon heating the wet solid biomass to around $200{ }^{\circ} \mathrm{C}$ to generate dry fuel. Pyrolysis mainly occurs in the temperature range of $150-900{ }^{\circ} \mathrm{C}$, where the cellulose, 
hemicellulose and lignin are decomposed into gases (such as $\mathrm{CO}, \mathrm{CO}_{2}$ and $\mathrm{CH}_{4}$ ), condensable liquids and carbon-rich char. The condensable liquid of "Tar" contains complex and various organic and inorganic compounds. The oxidation is a significant process occurring at more than $700{ }^{\circ} \mathrm{C}$, where the pyrolysis products (such as $\mathrm{CO}, \mathrm{CH}_{4}$ and $\mathrm{C}$ ) are oxidized to $\mathrm{CO}, \mathrm{CO}_{2}, \mathrm{H}_{2} \mathrm{O}$, etc in the presence of oxidants (e.g. air and $\mathrm{H}_{2} \mathrm{O}$ ). The main reactions during oxidation process are the endothermic oxidation reactions of pyrolysis products, as shown in Figure 2. In general, within the gasification process,, a series of reactions, such as cracking, reforming, condensation, polymerization, oxidation and gasification reactions, take place in the presence of air, steam and $\mathrm{CO}_{2}[16,17]$. The final products of the entire biomass gasification process contain synthetic gas (such as $\mathrm{H}_{2}, \mathrm{CO}, \mathrm{CO}_{2}$ and $\mathrm{CH}_{4}$ ), condensable tar, and solid char [18].

\section{$<$ Figure 2>}

Evans and Milne [19] classified the main processes of biomass gasification as the primary process (primary oxygenates), secondary process (hydrocarbon) and tertiary process (large aromatic). The conversion pathway of biomass gasification in the solid, liquid and vapor phases are presented in Figure 3. During the primary process, solid biomass is converted to primary oxygenated vapors, primary liquids and gaseous $\mathrm{H}_{2} \mathrm{O}, \mathrm{CO}$ and $\mathrm{CO}_{2}$ in the temperature range of 400-700 ${ }^{\circ} \mathrm{C}$. The primary oxygenated vapors are of lower molecular weight, including the monomers and monomer fragments of the biopolymers, such as levoglucosan, furfural, hydroxyacetaldehyde and methoxy phenols [20]. Only slight cracking reactions occur to generate lighter aromatics and oxygenates, and no chemical interactions are observed between the organic components of biomass during primary process.

During the secondary process, light olefins, aromatics, and gaseous $\mathrm{H}_{2} \mathrm{O}, \mathrm{H}_{2}, \mathrm{CO}$ and $\mathrm{CO}_{2}$ are generated from the cracking of methoxy phenols at $700-850^{\circ} \mathrm{C}$. In addition, the primary liquids form condensable oil that contains phenol and aromatics. For the tertiary process, the further increase of temperature to above $850-1000{ }^{\circ} \mathrm{C}$ leads to the continuous formation of polycyclic aromatic hydrocarbons (PAHs), as well as $\mathrm{CO}, \mathrm{H}_{2}, \mathrm{CO}_{2}$ and $\mathrm{H}_{2} \mathrm{O}$ through the high-temperature conversion process such as gasification and combustion. The tar compounds generally contain benzene, toluene, indene, naphthalene, anthracene, phenanthrene, and pyrene that are derived from the polymerization of the hydrocarbons with low molecular weight. In addition, the condensation of these tar compounds results in the formation of a liquid mixture at low temperatures.

In addition to the gaseous and liquid products, different kinds of solid products are also generated through different processes and defined on the basis of their origins. For example, charcoal is produced in the primary process and maintains the property of original lignocellulose. Both coke and soot are formed in the secondary and tertiary processes, where coke is derived from the thermolysis of the depositional liquid and organic vapors, and soot is produced from the homogeneous nucleation of the intermediates decomposed from the hydrocarbons in the vapor phase at high temperatures.

$<$ Figure 3>

\subsection{Tar issues}

Among the products derived from biomass gasification, the presence of tar in syngas is one of the most critical barriers limiting the commercial application of biomass gasification. Tar is a 
complex mixture of condensable organic compounds including single to multiple ring aromatic compounds, along with oxygenates and heavy PAHs [21, 22]. The content of tar varies from 1.0 to $100 \mathrm{~g} / \mathrm{m}^{3}$ depending on gasifer type, feed type and operation parameters, etc. [23]. The formation of tar will cause several problems, such as the loss of chemical energy in syngas, soot formation, and the decrease of overall energy efficiency [24, 25]. In addition, tar can condensate and polymerize to form heavier structures, leading to the contamination and plugging of pipe, engines, turbine, filter and heater exchanges, and the poison of catalysts during biomass gasification and biogas utilization [26-28]. Therefore, tar content generally should be controlled below $1.0 \mathrm{~g} / \mathrm{m}^{3}$ for the commercial application of fuel gas [29]. Based on this, the purification of fuel gas and the destruction of tar are necessary for the application of gasification technologies [30].

\subsection{The objectives of this review}

Based on the above analysis, the efficient and economic removal of undesirable tar in biomass gasification are reviewed in this work, aiming at giving guidance for future studies towards the commercial application of biomass gasification. Until now, catalytic steam reforming of tar has been widely reviewed in similar papers. For example, previous articles focused on reviewing different technologies for tar removal, such as physical methods, thermal removal, catalytic reforming, plasma reforming and partial oxidation, etc. [30-33]. In addition, some other review papers focused on catalytic reforming of tar by categorizing the catalysts as nickel-based catalysts, non-nickel based catalysts, alkali metal catalysts, basic catalysts, acid catalysts, active carbon catalysts, etc. [9, 14, 34-36]. Among the different kinds of catalysts, Ni-based steam-reforming catalysts have attracted much attention due to the high activity, low-cost and easy regeneration. However, the deactivation caused by the coke deposition and sintering remains the greatest challenge for their commercial application. Therefore, the modified Ni-based catalysts are now most frequently used for catalytic reforming of tar. At present, few review articles reported the modification methods and the development of Ni-based catalysts. Based on this, the preparation, modification and development methods of Ni-based catalysts for catalytic reforming of tar are reviewed in this paper, aiming at promoting the catalytic performance of conventional Ni-based catalysts, in terms of catalytic activity, long-term stability and selectivity towards low-molecular valuable compounds.

The research contributions will be summarized in the following sections.

- In section 2, the properties, formation mechanism and common removal methods of undesirable tar during biomass gasification are introduced. Then catalytic reforming of tar over Ni-based catalysts, as the most promising method, is presented. However, their disadvantages of the limited catalytic activity are also addressed, as well as the difficulty to be regenerated, the easy deactivation caused by sintering, carbon deposition and the poisoning of sulfur in biomass gasification.

- In section 3, based on the disadvantages of using traditional Ni-based catalysts during steam reforming of tar, the modification and development of Ni-based catalysts are summarized. This section is the core of this article. The methods of modifying Ni-based catalyst for catalytic tar reduction include (1) the activation of active metals by alloying with secondary metals such as other transition metals and noble metals; (2) the addition of promoters such as doping rare earth metals, alkaline-earth metals and alkali metals; (3) the enhancement of supporting materials and (4) the improvement of catalyst 
preparation methods by selecting appropriate Ni precursors, preparation modes, calcined temperature and $\mathrm{Ni} /$ promoter ratio.

- In section 4, the remarkable conclusions about the catalytic steam reforming of tar over modified Ni catalysts during biomass gasification are summarized.

\section{Steam reforming of biomass tar}

\subsection{Tar formation, properties and removal}

Tar is the most undesirable by-products during biomass gasification. The composition of tar is significantly varied based on the feedstock, the type of gasifier and gasification temperature. The dominant components of tar are changed from oxygenates with low molecular weight to light and heavy hydrocarbons with the increase of gasification temperature from 400 to $1000{ }^{\circ} \mathrm{C}$ (Figure 3). Different classification strategies have been proposed previously. On one hand, tar can be classified as primary, secondary and tertiary tar based on the three gasification processes as presented in Figure $3[15,37]$. On the other hand, tar can be divided into five classes based on the molecular weight, as shown in Table 2.

The pathways of primary, secondary and tertiary tar formation are complex, which contain cracking, polymerization, dehydrogenation, oxidation, and hydrogenation processes. Figure 4 shows the proposed mechanism of tar formation, assuming lignin as the biomass representative. The reaction pathway was deduced based on the most thermodynamically favorable reactions [37]. Lignin was firstly cracked to form three monomers of 2, 6-dimethoxyphenol $\left(\mathrm{C}_{8} \mathrm{H}_{10} \mathrm{O}_{3}\right)$, guaiacol $\left(\mathrm{C}_{7} \mathrm{H}_{8} \mathrm{O}_{2}\right)$ and furfural $\left(\mathrm{C}_{5} \mathrm{H}_{4} \mathrm{O}_{2}\right)$, typical primary tar compounds. The subsequent gasification led to the formation of secondary tars such as phenol, cresol, and xylene, etc. Phenol and cresol are the significant precursor of PAHs formation via precursor synthesis pathway [38]. Phenol was converted to cyclopentadiene by losing $\mathrm{CO}$ [39]. Then the produced cyclopentadiene underwent a Diels-Alder reaction, leading to the formation of dimer. This equilibrium system was rearranged by losing hydrogen to form the tertiary tars of naphthalene and indene [40]. With temperature increasing to over $800{ }^{\circ} \mathrm{C}$, the light PAHs recombined to heavy PAHs such as chrysene, pyrene and phenanthrene [41].

Considering the properties of the complex tar and the challenges of tar for syngas application, the removal of tar has been extensively studied. Generally, tar is removed or destructed after a gasifer, using mechanical separation (cyclone, wet scrubber, filter, and electrostatic precipitator) and thermal-chemical methods (thermal destruction [42, 43], catalytic steam reforming [44, 45], plasma reforming [24, 26, 46], partial oxidation [47, 48] and miscellaneous reforming [25]). The mechanical method can remove tar from flue gas, however, the secondary pollution and the loss of chemical energy in tar make it unattractive [34]. As for the thermal destruction of tar, a relative high temperature, generally over $1000{ }^{\circ} \mathrm{C}$ is needed, and thus leading to higher energy consumption with lower overall efficiency, and tougher requirements of equipment [49]. Non-thermal plasma (NTP) is conducted at ambient temperature and was reported to efficiently remove tar from biomass $(>95 \%)[50,51]$. However, the lower energy efficiency, lower selectivity of syngas and the undesired formation of by-products by using NTP limit its commercial application $[52,53]$. Among the different processes mentioned above, catalytic steam reforming seems to be an attractive alternative since it can convert tar to useful products at relative lower temperatures of around $600{ }^{\circ} \mathrm{C}[54]$. 


\subsection{Catalytic steam reforming of tar}

Catalytic steam reforming is a considerable attractive method in dual aspects of removing tar efficiently and simultaneously producing valuable syngas (mainly a mixture of $\mathrm{H}_{2}$ and $\mathrm{CO}$ ) [36, 56-58] During catalytic steam reforming of tar, a series of reactions take place simultaneously as shown in reaction (1)-(6), which may occur to different extents depending on the reaction conditions [59].

Steam reforming:

$$
\mathrm{C}_{\mathrm{n}} \mathrm{H}_{\mathrm{m}}(\operatorname{tar})+\mathrm{nH}_{2} \mathrm{O} \rightarrow(\mathrm{n}+\mathrm{m} / 2) \mathrm{H}_{2}+\mathrm{nCO}
$$

Dry reforming:

$$
\mathrm{C}_{\mathrm{n}} \mathrm{H}_{\mathrm{m}}(\operatorname{tar})+\mathrm{nCO}_{2} \rightarrow(\mathrm{m} / 2) \mathrm{H}_{2}+2 \mathrm{nCO}
$$

Thermal cracking:

$$
\mathrm{C}_{\mathrm{n}} \mathrm{H}_{\mathrm{m}}(\text { tar }) \rightarrow \mathrm{C}^{*}+\mathrm{C}_{\mathrm{x}} \mathrm{H}_{\mathrm{y}} \text { (smaller tar) }+ \text { gas }
$$

Hydrocracking/hydroreforming:

$$
\mathrm{C}_{\mathrm{n}} \mathrm{H}_{\mathrm{m}}(\mathrm{tar})+\mathrm{H}_{2} \rightarrow \mathrm{CO}+\mathrm{H}_{2}+\mathrm{CH}_{4}+\ldots+\text { coke }
$$

Water-gas shift (WGS) reaction:

$$
\mathrm{CO}+\mathrm{H}_{2} \mathrm{O} \rightarrow \mathrm{H}_{2}+\mathrm{CO}_{2}
$$

Methanation:

$$
\mathrm{CO}+3 \mathrm{H}_{2} \rightarrow \mathrm{CH}_{4}+\mathrm{H}_{2} \mathrm{O}
$$

Most tar is expected to be converted to syngas. However, non-converted tar and carbon deposition are always the problems. Therefore, one of the most important options is to use appropriate catalysts. During catalytic steam reforming of tar, the selection of catalysts should be based on the following standards [14, 15, 60, 61]: (I) high efficiency on tar removal; (II) suitable ratio of desired products (such as syngas); (III) high resistance to deactivation caused by metal sintering, coking and fouling; (IV) easy regeneration; (V) considerable mechanical strength for the commercial application; and (VI) low cost and easy availability.

Based on the multiple characters of steam reforming catalysts, it is reported that the supported metal catalysts (such as $\mathrm{Ni}, \mathrm{Co}, \mathrm{Fe}, \mathrm{Pt}, \mathrm{Pd}$ and combinations of metals) are most effective in catalytic destruction of tar [62-67]. Among these catalysts, Ni-based catalysts are most widely used due to its high activity, low cost and easy regeneration [54]. Besides, Ni-based catalysts exhibit a good activity/cost ratio. The high activity of Ni-based catalysts might be attributed to that metallic nickel is a main active component [68] to activate the $\mathrm{C}-\mathrm{H}$ and $\mathrm{C}-\mathrm{C}$ bonds of tar compounds [69]. It can also activate $\mathrm{H}_{2} \mathrm{O}$ and $\mathrm{CO}_{2}$ that participate in tar reforming [45] and WGS reactions [70-73]. Therefore, various Ni-based catalysts are commercial available for tar removal. The most commonly used supports for commercial Ni-based catalysts in steam reforming of tar are alumina $\left(\mathrm{Al}_{2} \mathrm{O}_{3}\right)$ and its modifications [59, 74].

Zhang et al. [75] investigated catalytic destruction of tar over commercial Ni-based catalysts , aiming at improving the yield of syngas. The tar conversion system was composed of a guard bed and catalytic reactor. Three commercial Ni-based catalysts labeled as ICI46-1, Z409 and RZ409 were proved to be effective in removing heavy tars with a destruction efficiency of $>99 \%$. Hydrogen yield was improved by 6-11 vol\% (dry basis) in the presence of the commercial 
catalysts. With temperature increasing, the hydrogen yield was increased and light hydrocarbons yield $\left(\mathrm{CH}_{4}\right.$ and $\left.\mathrm{C}_{2} \mathrm{H}_{4}\right)$ was reduced, indicating that tar decomposition was controlled by chemical kinetics. The obtained results also showed that the space velocity had little impact on gas compositions.

Coll et al. [76] studied the destruction of different model tar compounds (benzene, toluene, naphthalene, anthracene, and pyrene) in the presence of two commercial nickel catalysts (UCG90-C and ICI46-1) at 700-800 ${ }^{\circ} \mathrm{C}$. The reactivity of these model tars decreased in the sequence of benzene $>$ toluene $>$ anthracene $>$ pyrene $>$ naphthalene. Toluene conversion rate was in the range of $40-80 \%$ with the ICI $46-1$ catalyst, and $20-60 \%$ for the UCI G90-C catalyst.

Besides, Laosiripojana et al. [77] applied a $\mathrm{Ni} / \mathrm{Al}_{2} \mathrm{O}_{3}$ catalyst for catalytic reforming of ethanol to $\mathrm{H}_{2}$-rich syngas. The results showed that the $\mathrm{Ni} / \mathrm{Al}_{2} \mathrm{O}_{3}$ catalyst was deactivated rapidly and the selectivity of $\mathrm{H}_{2}$ was decreased by more than $30 \%$ within 20 min. Meanwhile, a huge amount of carbon deposition that caused the deactivation of catalyst was observed for the $\mathrm{Ni} / \mathrm{Al}_{2} \mathrm{O}_{3}$ (4.55 mmol/g-cat). Artetxe et al. [78] conducted catalytic steam reforming of different tar model compounds (phenol, toluene, methyl naphthalene, indene, anisole and furfural) over $\mathrm{Ni} / \mathrm{Al}_{2} \mathrm{O}_{3}$ catalysts. The highest conversions and $\mathrm{H}_{2}$ potential were obtained for anisole and furfural, while the methyl naphthalene demonstrated the lowest reactivity. Although higher reactivity was obtained for the oxygenates, carbon deposition on the catalyst was also promoted (in the 1.5-2.8 wt.\% range) compared with the catalytic reforming of aromatic hydrocarbons. The carbon conversion and $\mathrm{H}_{2}$ formation both increased with the increase of $\mathrm{Ni}$ loading from $5 \%$ to $20 \%$. However, these values decreased with increasing Ni loading further to $40 \%$ due to the increased Ni particle size and reduced specific surface area of the catalysts. Simultaneously, the formation of coke was increased with the increase of $\mathrm{Ni}$ loading and attained its maximum formation rate of $6.5 \mathrm{wt} . \%$ with the $40 \mathrm{wt} . \% \mathrm{Ni}$ catalyst.

Although Ni-based catalysts show high activity on catalytic tar removal, it should be noted that the presence of high temperature, high-pressure steam, hydrocarbons, and impurities create a severe environment for Ni-based steam reforming catalysts. These factors make the nickel steam-reforming catalysts encounter four challenges including activity, sulfur poisoning, carbon formation, and sintering, which are strongly interconnected [79-81]. Therefore, developing catalysts with high activity and resistance to deactivation caused by sintering, poisoning and coke deposition are of significant importance for catalytic steam reforming of tar.

It is proved that the activity and characteristics of catalysts mainly depend on the physical chemistry, structural and textural properties, such as active area, metal particle size, metal dispersion and reducibility. The mentioned properties depend on metal-support interaction, which can be manipulated by various methods. In order to enhance the sulfur tolerance, resistance to sintering and prohibition of carbon formation, several attempts have been made to modify catalyst preparation methods $[82,83]$ and add accessory promoters (such as noble metal or alkali) [79].

In this paper, the modification methods of conventional Ni steam-reforming catalysts were reviewed in relation to: (1) the modification of active metal ( $\mathrm{Ni}$ ) by alloying with other transition metals (e.g. Fe, $\mathrm{Co}, \mathrm{Mn}$ and $\mathrm{Cu}$ ) and noble metals (e.g. Pt, $\mathrm{Ru}, \mathrm{Pd}$ ); (2) the addition of various promoters such as rare earth metals (e.g. La, Ce, Pr, Sm), alkalis (e.g. K, Na, Li) and alkaline-earth metals (e.g. $\mathrm{Mg}, \mathrm{Ca}, \mathrm{Sr}, \mathrm{Ba}$ ); (3) the enhancement of supports by combining $\mathrm{Al}_{2} \mathrm{O}_{3}$ with additives or switching to novel non- $\mathrm{Al}_{2} \mathrm{O}_{3}$-based materials; (4) and the improvement of catalyst preparation methods by selecting optimizing nickel precursors and synthesizing methods. 


\section{Ni-based catalysts for Catalytic steam reforming of tar}

Active metal, promoter, support and preparation methods are considered to be the most important factors influencing the catalytic activities of catalysts [14, 84]. Therefore, the modification of Ni-based steam reforming catalysts are mainly reviewed in four aspects, covering the activation of active metals, the addition of promoters, the enhancement of supports and the optimization of preparation methods. The active site of the catalysts reviewed in this work is Ni. The addition of promoters could positively influence the catalytic activity, metal reducibility, the regenerability of spent catalysts and the resistance to catalyst deactivation. In addition, catalyst supports should supply a matrix with high specific surface area, good durability and resistance to coke and sintering [14]. In addition, the preparation methods can help synthesize catalysts with smaller metal nanoparticles, higher Ni dispersion and stronger metal-support interaction [85]. Table 3 shows a summary of catalytic conditioning studies using modified nickel-based catalysts.

$<$ Table 3>

\subsection{Influence of Ni precursors}

Ni steam reforming catalysts were most commonly prepared by impregnation method using a nickel precursor, followed by drying and thermal treatment. Therefore, the selection of $\mathrm{Ni}$ precursors is considered as one of the most important factors for the preparation of Ni-based catalysts. As reported in previous studies, the reduction degrees and dispersion of nickel, and the particle sizes of $\mathrm{Ni} / \mathrm{Al}_{2} \mathrm{O}_{3}$ catalysts closely depended on the anion size and property of nickel precursors [98-100].

Among different Ni compounds, nickel nitrate is the most commonly used precursor for the preparation of Ni-based catalysts due to the low cost, high water solubility and easily decomposing at moderate temperatures [101]. Park et al. [102] found that, with the exception of nickel nitrate, all the selected Ni-precursors (chloride and sulfate) caused obvious catalyst deactivation in the process of catalytic reforming. The conversion of benzene was less than $1 \%$ using $\mathrm{NiCl}_{2}$ due to the strong interactions between the $\mathrm{Cl}$ atoms inside the pore and the support. The catalysts prepared using the precursor of $\mathrm{Ni}\left(\mathrm{SO}_{4}\right)_{3} \cdot 6 \mathrm{H}_{2} \mathrm{O}$ exhibited even lower activity with negligible benzene conversion of $<0.2 \%$, which might be attributed to the poisoning of the catalyst by $\mathrm{H}_{2} \mathrm{~S}$ produced by reduction. Although the Ni-based catalysts prepared using nickel nitrate showed relative higher activity compoared with that prepared by nickel chloride and sulfate, the nickel particles derived from the nickel nitrate were easy to agglomerate over the support upon calcination, and thus lead to a poor dispersion of metal particles after reduction and the weak interaction between nickel and support [103].

Based on the results mentioned above, a multi-carboxylic nickel precursor was found to be a better choice to prepare efficient Ni-based catalysts [101, 104]. Wu et al. [98] investigated the effect of different nickel precursors, such as nickel nitrate (Ni-N), nickel chloride (Ni-C), nickel acetate (Ni-AC), and nickel acetylacetonate (Ni-AA), on the performance of steam reforming of glycerol (Figure 5). As revealed in Figure 5(a), the $\mathrm{Ni} / \mathrm{Al}_{2} \mathrm{O}_{3}$ prepared by nickel acetate (Ni-AC) possessed a moderate $\mathrm{Ni}$ reduction degree, high $\mathrm{Ni}$ dispersion, and small nickel particle size, leading to the highest $\mathrm{H}_{2}$ yield (Figure $5 \mathrm{~b}$ ) and the lowest coke production (Figure $5 \mathrm{c}$ ). The worst performance of the nickel chloride derived $\mathrm{Ni} / \mathrm{Al}_{2} \mathrm{O}_{3}$ catalysts might be attributed to the large $\mathrm{Ni}$ particle size, low $\mathrm{Ni}$ dispersion, and the presence of residual chloride [54]. In addition, the 
Ni-based catalysts prepared by nickel citrate precursor also exhibited greater NiO-support interaction, higher Ni dispersion and smaller nickel particles than that prepared from nickel nitrate [101].

Except for the conventional $\mathrm{Ni}$ precursors, further improvement has been obtained by selecting novel nickel precursors, such as a nickel-containing supramolecular framework $\left(\left(\mathrm{NO}_{3}\right)_{2} \mathrm{Ni}\left(\mathrm{H}_{2} \mathrm{O}\right)_{6}(\mathrm{HMA})_{2} \cdot 4 \mathrm{H}_{2} \mathrm{O}\right.$, HMA: hexamethylenetetramine) or a metal-organic $\left[\mathrm{Ni}_{4} \mathrm{O}_{4}\right]$ cubane cluster $[105,106]$. The obtained catalysts supported by SBA-15 were defined as HMA@Ni/SBA-15 and Ni4/SBA-15, respectively. A schematic illustration of the modified catalysts is shown in Figure 6 and 7. The developed HMA@Ni/SBA-15 and Ni4/SBA-15 catalysts demonstrated much higher catalytic activity and stability than the traditional Ni/SBA-15 prepared by $\mathrm{Ni}\left(\mathrm{NO}_{3}\right)_{2}$ and $\mathrm{Ni}(\mathrm{OAc})_{2}$ precursors, in relation to hydrocarbon conversion, hydrogen production and the prohibition of coke formation. The superior catalytic activity of the HMA@Ni/SBA-15 and Ni4/SBA-15 catalysts was suggested to be associated with the decreasing size of $\mathrm{NiO}$ nanoparticles, which could enhance $\mathrm{Ni}$ dispersion, improve reduction degree of $\mathrm{NiO}$ and strengthen the interaction between $\mathrm{Ni}$ and support.

Therefore, in order to obtain catalysts with outstanding catalytic performance in terms of the catalytic activity, stability and resistance to coke formation and sintering, the selection of $\mathrm{Ni}$ precursors is of significant importance. By comparing different studies, the organics-derived $\mathrm{Ni}$ precursors, especially with a cyclic or cubic structure, are beneficial to a higher dispersion of $\mathrm{Ni}$, smaller Ni particles and enhanced Ni-support interactions, which contribute to a higher catalytic performance of tar reduction.

\section{$<$ Figure 5 $>$ \\ $<$ Figure 6 $>$ \\ $<$ Figure 7 $>$}

\subsection{Influences of preparation and pre-treated methods}

Except for the selection of Ni precursors, the preparation method is another important factor that influences the catalytic activity [84]. Many efforts have been made to improve the preparation methods by changing the preparation procedure [84, 85, 95, 96, 107-111], adjusting the Ni loadings $[112,113]$ and the molar ratio of $\mathrm{Ni} /$ promoters $[107,114]$, and optimizing the preparation parameters [115-117]. It is known that the physicochemical features (total surface area, total pore volume and metal distribution) of catalysts prepared by various methods are significantly different [84].

The most conventional method for catalyst preparation is impregnation. Nahar et al. [108] prepared three different Ni-based catalysts (Ni supported on pre-calcined Ce-Zr prepared by wet impregnation, Ni supported on in-house calcined Ce-Zr prepared by wet and dry impregnation) for steam reforming of biodiesel. An in-house calcined $\mathrm{Ce}-\mathrm{Zr}$ was derived from the calcination of a $17 \mathrm{wt} \%$ cerium doped zirconia hydroxide at $600{ }^{\circ} \mathrm{C}$ for $6 \mathrm{~h}$, while a pre-calcined $\mathrm{Ce}-\mathrm{Zr}$ defined as a $17 \mathrm{wt} \%$ cerium doped zirconia oxide $\left(\mathrm{Ce}_{0.12} \mathrm{Zr}_{0.88} \mathrm{O}_{2}\right)$ was pre-calcined by the manufacture. They found that the Ni catalyst supported on the pre-calcined Ce-Zr prepared by wet impregnation had smaller crystallite size of $\mathrm{Ni}$, higher surface area and higher $\mathrm{Ni}$ dispersion, compared with the in-house calcined $\mathrm{Ce}-\mathrm{Zr}$ supported $\mathrm{Ni}$ catalysts prepared by wet and dry impregnation, as shown in Table 4. Oemar et al. [118] prepared two kinds of Sr-doped Ni/ $\mathrm{La}_{2} \mathrm{O}_{3}$ 
catalysts for steam reforming of toluene as a model tar compound. Co-impregnation and sequential impregnation methods were used to prepare A Ni-Sr/La $\mathrm{O}_{3}$ catalysts. The catalyst developed by co-impregnation method showed a better performance than the catalyst prepared by the sequential impregnation method under the same reforming temperature. Furthermore, $\mathrm{Sr}$ in the $\mathrm{Ni}-\mathrm{Sr} / \mathrm{La}_{2} \mathrm{O}_{3}$ catalyst derived from co-impregnation was located between $\mathrm{Ni}$ and $\mathrm{La}_{2} \mathrm{O}_{3}$ support. However, $\mathrm{Sr}$ in the sequential impregnation catalyst was located on the surface of $\mathrm{Ni} / \mathrm{La}_{2} \mathrm{O}_{3}$. The results indicated that $\mathrm{Sr}$ on the catalyst surface could enhance the catalytic activity and the stability of catalysts in catalytic steam reforming of tar.

The impregnation method usually produces large metal particles, a weak interaction between metal particles and support, and a large inhomogeneity in the composition of catalysts $[63,88,114]$. Therefore, hydrotalcite-like compounds (HTlcs) [88, 119-121], palygorskite-like compounds [95], mayenite-like compounds [79] and other kinds of co-precipitated catalysts $[110,122]$ attract increasing attention, since the preparation of uniform nanoparticles catalyst is important for the catalytic performance. Wang et al. [85] reported that Ni-based catalysts prepared by co-precipitation had smaller metal nanoparticles, higher dispersion and stronger metal-support interaction than that prepared by wet impregnation, leading to a more stabilized solid structure and lower metal reduction extent. $\mathrm{NiCu}$ and $\mathrm{NiFe}$ alloy catalysts derived from HTlcs prepared by Li et al. [88, 119-121] showed superior performance in terms of catalytic activity, stability, coke resistance and regenerability in steam reforming of biomass tar, due to the formation of well-dispersed and uniform $\mathrm{Ni}-\mathrm{Cu}$ and $\mathrm{Ni}-\mathrm{Fe}$ alloy nanoparticles. In addition, catalysts with high metal loadings (up to $78 \%$ ) and good dispersion could be obtained by co-precipitation method. For wet impregnation method, an exceed loading of metalscould cause the aggregation of large metal particles on the surface of support and result in a lower catalyst activity [110].

In addition, some other methods, such as sol-gel [96, 116], colloidal [109] ammonia evaporation [112], and hydrothermal treatment methods [111] etc., could also be promising alternatives for catalyst preparation. Higher catalytic activity for $\mathrm{H}_{2}$ production and tar conversion could be obtained using sol-gel than impregnation method, since the catalyst prepared by the sol-gel method has larger surface area and pore size. Moreover, the catalyst prepared by sol-gel method produced filamentous type carbons, which showed less negative effect on the catalytic activity than the amorphous type carbons, which were easily deposited over the impregnated catalysts, as shown in Figure 8 [96]. Ashok et al. [112] concluded that the metal-support interaction of $\mathrm{Ni} / \mathrm{SiO}_{2 \mathrm{p}}$ catalyst prepared by ammonia evaporation method was stronger than $\mathrm{Ni} / \mathrm{SiO}_{2}$ catalyst prepared by conventional impregnation methods. In addition, a better catalytic activity and a lower yield of tar and char were obtained over a $\mathrm{Ni} / \mathrm{SiO}_{2 p}$ catalyst. It might be caused by the formation of unique nickel phyllosilicate structures in the $\mathrm{Ni} / \mathrm{SiO}_{2 \mathrm{p}}$ catalyst.

Luo et al. [111] reported that a nano $\mathrm{Ni}_{\mathrm{x}} \mathrm{Mg}_{\mathrm{y}} \mathrm{O}$-hydro synthesized by hydrothermal method showed the most superior catalytic performance (97.4\% conversion of methanol and 58.5\% hydrogen yield) compared with those prepared by impregnation and co-precipitation methods. The $\mathrm{Ni}_{\mathrm{x}} \mathrm{Mg}_{\mathrm{y}} \mathrm{O}$-hydro also exhibited the highest stability and carbon deposition was negligible for $20 \mathrm{~h}$ at a $\mathrm{S} / \mathrm{C}$ ratio of 3 . Both nano-scale active phases in the $\mathrm{Ni}_{\mathrm{x}} \mathrm{Mg}_{\mathrm{y}} \mathrm{O}$ matrix and high micropore volume led to the high catalytic performance. The good anti-carbon deposition ability of the catalyst could be attributed to the "isolation effect" of the $\mathrm{Ni}_{\mathrm{x}} \mathrm{Mg}_{\mathrm{y}} \mathrm{O}$ solid solution 
structure that mitigated the agglomeration of $\mathrm{Ni}$ nanoparticles. In addition, the $\mathrm{MgO}$ support with a high total basicity was able to supply sufficient oxygen from the adsorbed $\mathrm{CO}_{2}$ and $\mathrm{H}_{2} \mathrm{O}$ to burn off amorphous carbon.

Based on the above analysis, the morphology, size and physiochemical properties could be adjusted by the preparation methods [84]. Among different synthesizing methods, hydrothermal, sol-gel and co-precipitation methods are more promising in increasing the catalytic performance compared with impregnation method. However, the catalysts that are synthesized by impregnation are still widely used, since the preparation method is much easier. Therefore, catalysts prepared by different methods could be selected according to different application aspects.

The calcination temperature was another significant parameter that could influence the incorporation of $\mathrm{NiO}$ into catalyst support and the consequent interaction between metal particles and the support, which was believed to be critical in avoiding Ni sintering and protecting the catalysts from coke formation [116]. It should be noted that an optimum calcination temperature was required depending on the species of supporting materials, e.g. 500 ${ }^{\circ} \mathrm{C}$ for $\mathrm{Fe}_{2} \mathrm{O}_{3}-\mathrm{Al}_{2} \mathrm{O}_{3}$ [117], $600{ }^{\circ} \mathrm{C}$ for $\mathrm{MgO}$ [123], 250-400 ${ }^{\circ} \mathrm{C}$ for $\mathrm{La}_{2} \mathrm{O}_{3}-\mathrm{ZrO}_{2}$ [115], and $800{ }^{\circ} \mathrm{C}$ for scallop shell $\left(\mathrm{CaO} / \mathrm{Ca}_{2} \mathrm{O}_{3}\right)[62]$.

Besides, adjusting the molar ratio of active metal/promoter and the active metal loadings could also improve the catalytic performance of steam reforming catalysts. For example, it was reported that increasing Ni loading led to a higher catalytic activity and stability $[124,125]$. However, for the Ni-based catalysts with promoters, a volcano-type trend was generally obtained by increasing the ratio of $\mathrm{Ni} /$ promoter. Catalysts with a $\mathrm{Ni} / \mathrm{Cu}$ ratio of $4: 1$ (varying from 1 to 10) supported on Mg-Al HTlcs exhibited the highest catalytic activity and the lowest by-product yield in steam reforming of 1-methylnaphthalene [88]. Kathiraser et al. [107] revealed that a SBA-15 supported Ni-Fe catalyst with a Ni/Fe ratio of 6:1 showed the highest gaseous product yield of $90 \%$ derived from biomass gasification.

\section{$<$ Figure 8 $>$ \\ $<$ Table 4 $>$}

\subsection{Influence of support materials}

A number of studies have focused on the effects of catalyst support on the performance of Ni-based catalysts for reforming reactions and biomass gasification, since the support materials is considered to be important on catalytic activity [126-130]. The accommodation of $\mathrm{Ni}$ in the support could improve Ni dispersion, suppress the aggregation of metal particles and control the particle size efficiently [131]. The catalyst support plays important roles during catalytic reactions by providing adsorption sites to the reactants, and interacting with active metals to obtain a new phase. Therefore, the properties of a catalyst, including the reducibility, metal dispersion, mechanical strength could be affected by acidity/basicity, specific surface area, pore structure, and electronic structure of the support [59]. The influence of support material on the catalytic performance can mainly be divided into the following five aspects as: (1) providing mechanical strength/integrity and thermal stability, (2) offering surfaces to disperse active metals, (3) playing a chemical role in catalysis, (4) developing an interaction with active metals, and (5) changing the product distribution [59, 132]. 
The most commonly used support for commercial Ni-based steam reforming catalyst is alumina. $\mathrm{Al}_{2} \mathrm{O}_{3}$ has been proved to be efficient for steam reforming reactions, however, a wide range of impurities e.g. char particles in tar reduced the catalytic activity of conventional Ni/ $\mathrm{Al}_{2} \mathrm{O}_{3}$ catalyst. Two promising method for improving the catalytic performance of $\mathrm{Ni} / \mathrm{Al}_{2} \mathrm{O}_{3}$ catalyst are the modification of $\mathrm{Al}_{2} \mathrm{O}_{3}$ support with an additive and changing to an absolutely different support [59].

The modification of $\mathrm{Al}_{2} \mathrm{O}_{3}$ support by adding promoters, such as rare metal oxides and alkaline-earth metals, will be discussed in the following sections. In this section, we aim at introducing other outstanding support materials. In previous studies, it can be noted that the effective supports for steam reforming catalysts could be classified as the following aspects: (1) acid supports such as $\gamma-\mathrm{Al}_{2} \mathrm{O}_{3}$; (2) basic supports such as $\mathrm{MgO}, \mathrm{CaO}$ and $\mathrm{CaCO}_{3}$; (3) rare earth oxides (REOs) such as $\mathrm{CeO}_{2}, \mathrm{La}_{2} \mathrm{O}_{3}$ and their mixtures; (4) mesostructured and high-ordered zeolites, such as SBA-15, ZSM-5, MCM-41, and ZY-type zeolites; (5) pretreated natural minerals, such as calcined olivine, dolomites and calcites; and (6) synthetic mineral-like supports, such as spinel, hydrotalcite-, palygorskite- and mayenite-like compounds. The detailed properties of different supports have been shown in Table 5. Among these different supports, group 3 to group 6 are considered to be more promising in relation to the promotion of catalytic performance.

$<$ Table 5>

REOs could be effective supporting materials due to their high oxygen storage capacity (OSC), good oxygen mobility and strong metal-support interactions. Park et al. [126] demonstrated that a $15 \mathrm{wt} \% \mathrm{Ni} / \mathrm{CeO}_{2}(75 \%)-\mathrm{ZrO}_{2}(25 \%)$ catalyst exhibited a better catalyst performance in terms of catalytic activity, stability and ability of anti-carbon formation, compared with several commercial $\mathrm{Ni}$ catalysts and a lab-prepared $\mathrm{Ni} / \gamma-\mathrm{Al}_{2} \mathrm{O}_{3}$ catalysts. The superior catalytic activity of the $\mathrm{Ni} / \mathrm{CeO}_{2}-\mathrm{ZrO}_{2}$ catalyst was attributed to its greater redox characteristics and increased specific surface area. García-García et al. [148] revealed that a Ni catalyst supported on $\mathrm{CeO}_{2}$ showed the highest hydrogen yield in steam reforming of m-cresol at $700{ }^{\circ} \mathrm{C}$, among several $\mathrm{Ni}$ catalysts supported on $\gamma-\mathrm{Al}_{2} \mathrm{O}_{3}, \alpha-\mathrm{Al}_{2} \mathrm{O}_{3}$, olivine sand, zircon sand and $\mathrm{La}_{2} \mathrm{O}_{3} / \gamma-\mathrm{Al}_{2} \mathrm{O}_{3}$. Its outstanding performance could be attributed to the higher surface area, the enhanced metal dispersion and the stronger interaction of the metal and the support [153]. Although $\mathrm{La}_{2} \mathrm{O}_{3}$ showed almost no impact on the yield of hydrogen, the stability of the catalyst was improved.

Natural minerals, such as calcined olivine, dolomites and calcite, have been extensively used as the supports of steam reforming catalysts, because they are inexpensive, non-toxic, disposable and these materials-based catalysts have high activity at high temperatures [154]. Dolomite generally contains $30 \mathrm{wt} \% \mathrm{CaO}, 21 \mathrm{wt} \% \mathrm{MgO}, 45 \mathrm{wt} \% \mathrm{CO}_{2}$, and trace amounts of minerals such as $\mathrm{SiO}_{2}, \mathrm{Fe}_{2} \mathrm{O}_{3}$ and $\mathrm{Al}_{2} \mathrm{O}_{3}$. It is active in tar removal, and is well-known for its $\mathrm{CO}_{2}$-capture abilities. Several studies used calcined dolomites $(\mathrm{MgO}-\mathrm{CaO})$ for the elimination of tar, which could be obtained by decomposing dolomite $\mathrm{CaMg}\left(\mathrm{CO}_{3}\right)_{2}$ at high temperatures ranging from 800 to $900{ }^{\circ} \mathrm{C}$ [35]. Calcined dolomite catalyst is more active for tar decomposition compared to un-calcined dolomite, owing to its larger (internal) surface area and higher oxide contents on the surface of the catalyst [14]. Siedlecki et al. [155] reported that the activity of $\mathrm{CaO}-\mathrm{MgO}$ was higher than $\mathrm{CaO}$ and $\mathrm{MgO}$ for tar conversion, and the gas yield was in the sequence of calcined dolomite $(\mathrm{CaO}-\mathrm{MgO})>$ calcined magnesite $(\mathrm{MgO})>$ calcined calcite $(\mathrm{CaO})$. The addition of $\mathrm{Ni}$ 
in calcined dolomite promoted the tar reduction effectively. Chang et al. [156] found that the yield increased by $33 \%$ for $\mathrm{H}_{2}$, increased by $7 \%$ for syngas, and decreased by $59 \%$ for $\mathrm{CH}_{4}$ over a $\mathrm{Ni} /$ dolomite at $900{ }^{\circ} \mathrm{C}$, compared with calcined dolomite catalysts without $\mathrm{Ni}$ loading.

Calcined dolomite based materials are considered to be effective catalysts for the destruction of oxygenated compounds, typically derived from steam gasification of biomass. However, the catalysts are less effective for the removal of PAHs that produced from air-blown gasification. In addition, calcined dolomite has the problems of easy erosion, due to its soft and fragile properties, which limits its application in fluidized-bed reactor [35].

Olivine, as an iron-bearing mineral $(\mathrm{Fe}, \mathrm{Mg})_{2} \mathrm{SiO}_{4}$, is also considered as a promising steam reforming catalyst due to its optimal hardness. It can provide a good resistance to attrition, used at high temperature with a low yield of carbonaceous deposition [151]. Therefore, olivine is of particular interest for the in situ tar removal in fluidized-bed biomass gasification. $\mathrm{NiO}$ was generally grafted with or integrated into calcined olivine support to prevent attrition, sintering and the volatilization of nickel [157]. Ni/olivine as a low-cost catalyst could provide high stability and resistance for repeated high temperature processing in oxidizing $\left(900{ }^{\circ} \mathrm{C}\right)$ and reducing $\left(850^{\circ} \mathrm{C}\right)$ atmosphere during circulation [158]. It is noteworthy that a fraction of $\mathrm{NiO}$ incorporated into olivine structure preventing the loss of $\mathrm{Ni}^{0}$ formed during the reduction of $\mathrm{NiO}$ [159]. In the study of Świerczyński et al. [160], a superior catalytic performance was obtained for a Ni/olivine catalyst, with higher catalytic activity, higher selectivity of $\mathrm{H}_{2}$ and $\mathrm{CO}$, and lower yield of carbon deposition by comparing with olivine alone [147]. A Ni/olivine catalyst with an optimal loading of $3.9 \mathrm{wt} \% \mathrm{Ni}$ was prepared with nitrate nickel and calcined at $1100{ }^{\circ} \mathrm{C}$. Almost a total toluene conversion was obtained at temperature above $650{ }^{\circ} \mathrm{C}$. Characterization of catalyst indicated the presence of a particular structure of $\mathrm{Ni}-\mathrm{Fe} / \mathrm{MgO} / \mathrm{olivine}$ in the reduced catalyst, which contributed to the excellent stability. Both $\mathrm{Ni}-\mathrm{Fe}$ alloys and basic $\mathrm{MgO}$ oxide were beneficial for the suppression of carbon deposition, because Ni-Fe alloys could prevent carbon deposition by dilution effect, and $\mathrm{MgO}$ could enhance the steam adsorption, and consequently facilitate the gasification of surface carbon [147].

Apart from the traditional natural materials, Guan et al. [62] also applied other natural material, i.e. calcined scallop shell (CS), for steam reforming of tar. Various irregular particles were attached on the surface of the shell for the un-calcined CS. However, the porous structure was clearly observed on the surface of the calcined CS at $800{ }^{\circ} \mathrm{C}$, as shown in Figure 9. As indicated in Figure 10, the main compositions of the calcined CS at 600,800 , and $1000{ }^{\circ} \mathrm{C}$ for $5 \mathrm{~h}$ were calcite $\left(\mathrm{CaCO}_{3}\right), \mathrm{CaO}$ and $\mathrm{CaCO}_{3}$, and $\mathrm{CaO}$, respectively, which were significantly affected by the calcination temperature. However, the $\mathrm{CS}$ calcined at $1000{ }^{\circ} \mathrm{C}$ showed a weak mechanical strength, and was very easily crushed into fine powders. Thus, CS calcined at $800{ }^{\circ} \mathrm{C}$ was considered to a more suitable catalyst for tar reduction due to its mechanical strength. The results demonstrated that the metallic forms of iron and nickel were considered as active sites for the reforming of tar rather than their oxide ones. At the beginning, $\mathrm{NiO} / \mathrm{CS}$ and $\mathrm{Fe}_{2} \mathrm{O}_{3} / \mathrm{CS}$ showed little catalytic activity. The good activity appeared after approximately $30 \mathrm{~min}$ of reaction, owing to the reduction of metal oxide to its metallic form by the self-generated syngas $\left(\mathrm{CO}\right.$ and $\left.\mathrm{H}_{2}\right)$ produced from biomass pyrolysis. In addition, the alkaline elements in biomass could enhance the activity of catalysts. The alkaline metals were accumulated on the surface of the catalyst together with the biomass-derived tar. Therefore, a larger quantity of syngas was produced when the regeneration of catalyst was applied. A possible catalytic process was proposed in Figure 11. 


\section{$<$ Figure 9> \\ $<$ Figure 10 $>$ \\ $<$ Figure 11 $>$}

As an important class of crystalline aluminosilicates, zeolites have also been widely used in heterogeneous catalysis due to the well-defined pore structures, extremely high surface area, and high surface acidity [144]. The advantages of using zeolites over amorphous catalysts mainly include [145]: (1) the adjustable acidity, (2) better thermal/hydrothermal stability, (3) higher specific surface area, (4) better resistance to nitrogen and sulfur compounds, (5) tendency toward low coke formation, and (6) easy regeneration ability. The confinement effect of mesoporous materials can efficiently stabilize the Ni particles during the reduction process, which accounts for the long-term stability [105]. Therefore, zeolite supported catalysts are of great potential in tar elimination. Buchireddy et al. [145] reported that nickel-supported ZY-30 and ZY-80 exhibited the highest naphthalene conversions of over $99 \%$ for $97 \mathrm{~h}$, followed by nickel-supported ZY-5.2, $\mathrm{SiO}_{2} / \mathrm{Al}_{2} \mathrm{O}_{3}$, and chabazite. Wang et al. [131] conducted steam reforming of ethanol over Ni-based oxygen carriers (OCs) with different supports including alloy $\mathrm{Ni}_{2} \mathrm{Al}_{2} \mathrm{O}_{3}$, lamellar Ni/MMT, mesoporous Ni/Al-MCM-41 and mesoporous Ni/SBA-15. As presented in Figure 12, Ni/SBA-15 exhibited the most efficient confinement effect followed by Ni/Al-MCM-41, Ni/MMT and $\mathrm{Ni} / \mathrm{Al}_{2} \mathrm{O}_{3}$ via: 1) small nickel particle size and high dispersion as well as strengthened metal-support interaction; 2) sintering resistance due to the spatial restriction of support; and 3) anti-coke capability derived from small nickel particles and ordered diffusion routes for reactants and products. The silica supported OCs (Ni/SBA-15 and Ni/MMT) were conductive to promote WGS reaction, but the supports containing $\mathrm{Al}$ atoms (Ni/Al-MCM-41 and $\mathrm{Ni} / \mathrm{Al}_{2} \mathrm{O}_{3}$ ) were favorable for coke deposition due to the formation of acid sites. The Ni/Al-MCM-41 exhibited an excellent activity in initial cycle, however, the deactivation and sintering of active sites resulted from the collapse of the Ni/Al-MCM-41 structure happened due to the weak thermo-stability [44]. Ye et al. [161] investigated the acidity of Ni/MCM-41 catalyst for tar reduction in biomass gasification. The catalyst with higher acidic sites produced higher hydrogen. However, the formation of coke on the catalyst was also slightly promoted. Furthermore, Ni/MCM-41 catalyst was used for the reduction of tar, in relation to the location of Ni metal particles [162]. Adding 10 wt.\% Ni particles inside the pores of MCM-41 was found to increase the production of hydrogen and reduce the formation of coke on the surface of the spent catalyst, compared to locating most of the Ni species on the surface of the MCM-41 support.

\section{$<$ Figure 12>}

In addition, Ni-based catalysts supported on synthetic minerals, such as hydrotalcite-, palygorskite-, perovskite- and mayenite-like compounds, showed excellent performance in steam reforming of tar, due to the formation of smaller metal nanoparticles, higher metal dispersion and stronger metal-support interaction [85]. Soongprasit et al. [163] reported that $\mathrm{La}_{0.6} \mathrm{Ce}_{0.4} \mathrm{NiO}_{3}$ catalyst could promote the conversion of toluene to $\mathrm{CO}$ and $\mathrm{H}_{2}$, reaching the highest yield of $57.26 \%$ for $\mathrm{CO}$ and $76.62 \%$ for $\mathrm{H}_{2}$ at $800{ }^{\circ} \mathrm{C}$, respectively. The catalysts showed good stability and no deactivation were observed for $3 \mathrm{~h}$. This could be attributed to the presence of smaller particles, 
bigger specific surface area and improved reducibility of the perovskite catalyst. In the study of Laosiripojana et al. [97] demonstrated that $\mathrm{Ni}-\mathrm{Fe}$ supported by $\mathrm{MgO}-\mathrm{Al}_{2} \mathrm{O}_{3}$ and $\mathrm{La}_{0.8} \mathrm{Ca}_{0.2} \mathrm{CrO}_{3} / \mathrm{MgO}-\mathrm{Al}_{2} \mathrm{O}_{3}$ showed a higher $\mathrm{H}_{2}$ yield and good resistance to carbon deposition, compared with palygorskite and $\mathrm{La}_{0.8} \mathrm{Ca}_{0.2} \mathrm{CrO}_{3}$ supported catalysts, as presented in Figure 13. The superior catalytic performance of these two catalysts might be attributed to the formation of magnesium aluminate spinel, which offered enhanced $\mathrm{O}$ and $-\mathrm{OH}$ anion spillover from the support surface onto the metallic particle [164, 165]. Moreover, the $\mathrm{H}_{2}$ yield was significantly influenced

by $\mathrm{H}_{2} \mathrm{O} / \operatorname{tar}$ and $\mathrm{CO}_{2} / \operatorname{tar}$ ratios, particularly for the $\mathrm{Ni}-\mathrm{Fe} / \mathrm{La}_{0 .} \mathrm{Ca}_{0.2} \mathrm{CrO}_{3} / \mathrm{MgO}-\mathrm{Al}_{2} \mathrm{O}_{3}$ and $\mathrm{Ni}-\mathrm{Fe} / \mathrm{La} 0.8 \mathrm{Ca}_{0.2} \mathrm{CrO}_{3}$ due to the presence of perovskite-based $\mathrm{La}_{0.8} \mathrm{Ca}_{0.2} \mathrm{CrO}_{3} . \mathrm{La}_{0.8} \mathrm{Ca}_{0 .} \mathrm{CrO}_{3}$ behaved like a partly-reduced metal-oxide catalyst promoting the reforming activity at optimal

\section{$\mathrm{H}_{2} \mathrm{O} /$ tar and $\mathrm{CO}_{2} /$ tar ratios. $<$ Figure 13>}

\subsection{Modification of Ni-based catalysts}

Except for the preparation methods and supporting materials, the catalytic performance of Ni-based steam reforming catalysts could also be modified by the activation of $\mathrm{Ni}$ active site (alloying with secondary transition metals and noble metals) and the addition of various promoters (rare earth oxides, alkaline-earth metals and alkali metals).

\subsubsection{Alloying with secondary transition metals}

The performances of Ni-based catalysts can be improved by the addition of secondary metals as promoters, such as $\mathrm{Fe}, \mathrm{Co}, \mathrm{Mn}$, and $\mathrm{Cu}$, etc. [87, 107, 112]. The promotion effect of these secondary transition metals might be attributed to the formation of Ni-Me (Me: secondary transition metals) alloys [56].

Among these metals, $\mathrm{Fe}$ is considered to be a promising choice due to its good redox properties. Previous study showed that the intimate interaction between $\mathrm{Fe}$ and $\mathrm{Ni}$ led to the formation of a Ni-Fe alloy, and then resulted in the improvement of steam reforming activity of $\mathrm{Ni}-\mathrm{Fe} / \mathrm{Al}_{2} \mathrm{O}_{3}$ catalysts [58]. Adding $\mathrm{Fe}$ into $\mathrm{Ni}-\mathrm{Al}$ based catalyst was reported to reduce hydrogen production slightly during gasification of wood sawdust [166]. However, the prohibition of coke formation on the reacted catalyst was enhanced. Ashok et al. [56] applied iron-alumina-supported nickel-iron alloy catalysts (NFA) for steam reforming of toluene as a model tar compound. $\mathrm{Ni}$ supported on a $\mathrm{Fe}_{2} \mathrm{O}_{3}-\mathrm{Al}_{2} \mathrm{O}_{3}$ support calcined at $500{ }^{\circ} \mathrm{C}$ [NFA (500)] showed the best catalytic activity and stability for $26 \mathrm{~h}$ with a $\mathrm{H}_{2} / \mathrm{CO}$ value of 4.5 . The superior catalytic performance of the NFA (500) could be attributed to the synergy between $\mathrm{Ni}$ and $\mathrm{Fe}$ atoms in terms of forming Fe-rich $\mathrm{Ni}-\mathrm{Fe}$ alloy particles and the strong metal-support interactions. In addition, a larger amount of surface active metal species and available lattice oxygen species, and higher catalyst surface area also played important roles in the promotion of reforming activity of the NFA (500) catalyst. Li et al. [121] evaluated the performance of Ni-Fe-Mg-Al catalysts at 823-923 K in steam reforming of biomass tar derived from Cedar wood (particle sizes of $0.1-0.3 \mathrm{~mm}$ ). The results indicated that the $\mathrm{Ni}-\mathrm{Fe} / \mathrm{Mg} / \mathrm{Al}$ catalyst with an optimized $\mathrm{Fe} / \mathrm{Ni}$ ratio $(0.25)$ exhibited the highest catalytic activity and catalyst stability, resulting in a tar conversion of almost $100 \%$, much higher than $80 \%$ catalyzed by the $\mathrm{Ni} / \mathrm{Mg} / \mathrm{Al}$ and $24 \%$ by the $\mathrm{Fe} / \mathrm{Mg} / \mathrm{Al}$ catalyst. In addition, the $\mathrm{Ni}-\mathrm{Fe}$ catalysts were easier to be regenerated by the oxidation-reduction treatment for the removal of coke. The characterization of the Ni-Fe catalysts indicated that its superior catalytic performance should be attributed to the formation of uniform Ni-Fe alloy NPs and the synergetic effect of Ni and Fe. 
$\mathrm{Co}, \mathrm{Mn}$ and $\mathrm{Cu}$ were also considered as promising co-catalysts in steam reforming of biomass tar [167]. Wang and his coworkers [114] investigated the performances of $\mathrm{Ni}-\mathrm{Co} / \mathrm{Al}_{2} \mathrm{O}_{3}$ catalysts in steam reforming of tar from pyrolysis of cedar wood at $923 \mathrm{~K}$. The $\mathrm{Ni}-\mathrm{Co} / \mathrm{Al}_{2} \mathrm{O}_{3}$ catalyst with an optimizing $\mathrm{Ni} / \mathrm{Co}$ ratio of 0.25 exhibited much higher catalytic performance in relation to the catalytic activity, the resistance to coke formation and catalyst lifetime compared to the corresponding monometallic $\mathrm{Ni}$ and Co catalysts. This behavior was attributed to the formation of Ni-Co solid solution alloys. Koike et al. [168] investigated the effect of $\mathrm{MnO}_{\mathrm{x}}$ on steam reforming of toluene over a $\mathrm{Ni} / \mathrm{Al}_{2} \mathrm{O}_{3}$ catalyst. The results indicated that the catalytic performance was enhanced obviously due to the mobility of oxygen from neighboring $\mathrm{MnO}_{\mathrm{x}}$ to carbonaceous intermediates. $\mathrm{Li}$ et al. [88] prepared $\mathrm{Ni}-\mathrm{Cu}$ alloy nanoparticles for steam reforming of 1-methylnaphthalene (1-MN). The results indicated that the Ni-Cu alloy NPs showed much higher catalytic activity than the Ni-based catalyst, and the best reforming performance was obtained over the catalyst with a $\mathrm{Cu} / \mathrm{Ni}$ ratio of 0.25 , with the highest conversion of $1-\mathrm{Mn}(100 \%)$, the highest formation rate of syngas and the lowest yields of undesirable by-products (benzene, naphthalene and coke). It could be attributed to the stronger dissociative adsorption of steam on $\mathrm{Ni}-\mathrm{Cu}$ alloy nanoparticles. Therefore, more adsorbed oxygen species were formed, and subsequently the gasification of carbonaceous species was enhanced, leading to a higher activity and a lower coke deposition.

Based on the above analysis, the formation of alloys, obtained through strong interaction between $\mathrm{Ni}$ and co-catalyst species, is a crucial entity in preparing bimetallic and polymetallic catalysts for steam reforming of tar [56].

\subsubsection{Doping with noble metals}

Noble metals (NM), such as $\mathrm{Pt}, \mathrm{Pd}, \mathrm{Rh}, \mathrm{Ru}, \mathrm{Ir}, \mathrm{Au}$, etc., could also be used as efficient co-catalyst species, due to the high catalytic activity, good resistance to carbon formation and sulfur tolerance in steam reforming processes [169]. This is because that the kinetics of carbon gasification on noble metals are fast and the low carbon solubility in their bulk is against to the growth of carbons [170]. The commercial application of noble metal catalysts with high loadings was limited due to their high cost $[62,64]$. In most cases, however, noble metals with trace amounts could be regarded as the promoter for Ni-based catalysts.

Chen et al. [90] compared the activity of different monometallic and bimetallic Ni catalysts (Ni-Fe, Ni-Cu, IrNi, RhNi, PtNi, RuNi, AuNi and PdNi) in stream reforming of biomass tar, as shown in Figure 14. The results indicated that the addition of noble metals improved the catalytic activity of Ni-based catalysts, and the PdNi catalyst showed the highest performance among the noble metal added catalysts. In addition, the PdNi catalyst was proved to be more promising than the Ni-Fe and $\mathrm{Ni}-\mathrm{Cu}$ catalysts in terms of activity, catalyst lifetime and the resistance to coke deposition [86]. The highest catalytic performance of the PdNi catalyst should be attributed to the enhanced reducibility of Ni species and the dispersion of Ni metal particles simultaneously [171]. Luciene et al. $[172,173]$ demonstrated that PdNi and PtNi catalysts exhibited a higher catalytic performance than IrNi and RuNi in steam reforming of ethanol and glycerol. It might be attributed to the obvious decrease of reduction temperature of $\mathrm{NiO}$ speciesby the in-situ generated hydrogen. The active Ni sites were stabilized in the reduced state throughout the reaction with the added noble metals, leading to the increase of tar conversion and the decrease of coke formation. In addition, other studies also revealed that the addition of noble metals could alleviate the sintering 
of Ni-based catalysts by forming Ni-NM alloys [174-176].

Generally, the catalytic activity of noble metals is significantly different in various cases. In previous studies, an activity order of $\mathrm{Pd}>\mathrm{Ir}>\mathrm{P} t \sim \mathrm{Rh}>\mathrm{Ru}>\mathrm{Ni}$ was given in steam reforming of methane [177]. However, Dagle et al. [169] reported that Ir and Rh showed better performance than $\mathrm{Ni}, \mathrm{Ru}, \mathrm{Pt}$ and $\mathrm{Pd}$ in terms of activity and stability in steam reforming of methane containing benzene and naphthalene. The catalytic mechanism of IrNi catalyst for steam reforming of biogas containing tar was given by combining the theoretical calculation (ab initio molecular dynamic (AIMD) simulations) and experimental results. The optimized structures of the monometallic (Ni and Ir) and bimetallic IrNi catalysts are presented in Figure 15(a), along with the atoms distribution in the direction along the surface normal. A well-mixed Ni-Ir alloy was obtained in the gas-phase $\mathrm{Ir}_{5} \mathrm{Ni}_{45}$ cluster. For the energetics of decomposing the simple hydrocarbon $\mathrm{CH}_{4}$ to $\mathrm{CH}_{3}+\mathrm{H}, \mathrm{CH}_{2}+2 \mathrm{H}, \mathrm{CH}+3 \mathrm{H}$ and $\mathrm{C}+4 \mathrm{H}$ (Figure 15b), the relative energetics of the last reaction: $\mathrm{CH}+3 \mathrm{H} \rightarrow \mathrm{C}+4 \mathrm{H}$ was taken as the propensity of the clusters to form coke. As shown in Figure 15(b), both $\mathrm{Ni}_{50}$ cluster and isolate $\operatorname{Ir}$ on $\operatorname{Ir}_{5} \mathrm{Ni}_{45}$ were more favorable for the coke formation $\left(\Delta \mathrm{E}_{\mathrm{CH} / \mathrm{C}}<0 \mathrm{~kJ} / \mathrm{mol}\right.$ ). Conversely, a $\Delta \mathrm{E}_{\mathrm{CH} / \mathrm{C}}$ of $63 \mathrm{~kJ} / \mathrm{mol}$ was obtained for the $\operatorname{Ir}_{5} \mathrm{Ni}_{45}$, which was much higher than that of the $\operatorname{Ir}_{50}$ and $\operatorname{Ir}_{25}$. In addition, Figure 15(c) shows the reaction energy profile for carbon monoxide formation, and small Ir5Ni45 cluster supported on spinel exhibited the highest energetic preference for $\mathrm{CO}$ formation. Therefore, the Ir sites on alloyed Ir-Ni nanoparticles showed higher performance on the promotion of $\mathrm{CO}$ formation and the resistance to coke formation. For steam reforming of syngas containing tar over the IrNi system, small Ir clusters ( 2-3 atoms) on the surface of larger Ni-rich particles ( $\geq 5 \mathrm{~nm})$ resulted in electron-rich Ir sites. These sites led to the improved durability and activity of the Ir-Ni catalysts compared with the catalyst with Ni or Ir alone.

\section{$<$ Figure 14 $>$}

$<$ Figure 15 $>$

\subsubsection{Doping with rare earth oxides (REOs)}

Rare earth oxides (REOs) are widely recognized as redox promoters which can improve the system's electronic properties by increasing the metal-support interaction and the oxygen storage capacity of catalyst $[178,179]$. Therefore, REOs (such as $\mathrm{La}_{2} \mathrm{O}_{3}, \mathrm{CeO}_{2}, \mathrm{Pr}_{6} \mathrm{O}_{11}, \mathrm{Sm}_{2} \mathrm{O}_{3}$, etc.) were extensively used for steam reforming of $\operatorname{tar}$ [180-183]. The addition of REOs to Ni-based catalysts lead to the improvement of metallic dispersion, the increase of redox properties, the minimization of metal sintering and the enhancement of the resistance to carbon deposition and sulfur poisoning [181-185]. These behaviors could be attributed to the enhanced generation of oxygen vacancies in doped REOs [181, 186].

Among different REOs, $\mathrm{CeO}_{2}$ was considered as a promising promoter of steam reforming catalysts, since $\mathrm{CeO}_{2}$ exhibited higher catalytic performance than other REOs, such as La and $\mathrm{Pr}$ $[143,179,183]$. The higher activity of $\mathrm{CeO}_{2}$ in steam reforming reactions can be attributed to the outstanding redox characteristics of high oxygen transfer capability and oxygen storage capacity [102, 187-189]. Muñoz et al. [179, 185] showed that the introduction of redox promoters, such as $\mathrm{Ce}$ and $\mathrm{Pr}$, improved the reducibility, basicity (in terms of strength) and oxygen mobility of the Ni-Co catalysts. As a consequence, the carbon gasification and WGS reaction were promoted by the addition of REOs. For steam reforming reactions on $\mathrm{CeO}_{2}$-promoted $\mathrm{Ni}$ catalysts, more 
oxygenated species (such as the $-\mathrm{O}$ and $-\mathrm{OH}$ groups) were produced, when water was adsorbed dissociatively on the support or on the lattice oxygen at the interface of metal and redox support. As a consequence, the carbonaceous components deposited on the catalyst surface could be easily gasified during reforming of tar [102, 187]. Ashok et al. [190] applied $\mathrm{CeO}_{2}$-promoted $\mathrm{Ni} / \mathrm{CaO}-\mathrm{Al}_{2} \mathrm{O}_{3}$ catalysts for steam reforming of toluene. A series of characterizations of catalysts (XRD, TPR, XPS, $\mathrm{CO}_{2}$-TPD, TGA, CO pulse chemisorption and Hammett indicator methods) were conducted for the analysis of catalytic mechanism. The results indicated that the $\mathrm{Ni} / \mathrm{Ca}-\mathrm{Al}-\mathrm{Ce}(0.2)$ showed superior catalytic performance due to its higher surface basicity and basic strength, higher amount of surface metallic nickel, enhanced reducibility of supported nickel species by the redox property of $\mathrm{CeO}_{2}$, and stronger interaction between $\mathrm{Ni}$ and $\mathrm{Ce}$ species.

$\mathrm{La}_{2} \mathrm{O}_{3}$ is another promising REO which is frequently used for the promotion of Ni-based catalysts except for $\mathrm{CeO}_{2}$. Garbarino et al. [92] prepared $\mathrm{La}_{2} \mathrm{O}_{3} / \gamma-\mathrm{Al}_{2} \mathrm{O}_{3}, \mathrm{NiO} / \gamma-\mathrm{Al}_{2} \mathrm{O}_{3}$ and $\mathrm{NiO} / \mathrm{La}_{2} \mathrm{O}_{3} / \gamma-\mathrm{Al}_{2} \mathrm{O}_{3}$ catalysts for steam reforming of ethanol and phenol as model tar compounds. They found that a surface $\mathrm{Ni}_{\mathrm{x}} \mathrm{Al}_{2} \mathrm{O}_{3+\mathrm{x}}$ spinel was formed on the Ni/alumina catalyst. In addition, $\mathrm{Ni}-\mathrm{La}$ interactions were observed in the ternary $\mathrm{Ni}-\mathrm{La} / \mathrm{Al}_{2} \mathrm{O}_{3}$ system. The addition of lanthanum ( $20 \%$ of $\mathrm{La}_{2} \mathrm{O}_{3}$ ) improved the activity of $\mathrm{Ni} / \mathrm{Al}_{2} \mathrm{O}_{3}$ for steam reforming of ethanol and phenol. However, the resistance to sulfur deactivation was not improved.

REOs can not only be used as promoters and additives in Ni-based catalysts, but they can also be used as alternative supports to improve the catalytic performance of nickel in steam reforming reactions. This is not only because it has interesting redox properties, but also because it can modify the properties of active metals by strong metal-support interactions [191-195].

\subsubsection{Promotion with alkaline-earth metals}

During steam reforming of tar over alumina supported catalysts, the acid sites of alumina promoted the carbon deposition, leading to the decrease of catalyst stability and the increase of reaction backpressure. One of the promising approaches to minimize carbon formation is to promote its gasification by modifying the support with alkaline earth metals such as $\mathrm{Mg}, \mathrm{Ca}, \mathrm{Sr}$ and $\mathrm{Ba}[196,197]$. These additives exhibited strong water adsorption and $\mathrm{OH}$ surface mobility, decreasing the rate of coke deposition on catalyst surface [198]. The modification methods can be classified into two aspects: (1) promoting steam reforming reactions and decreasing the acidity of catalysts by the addition of alkaline earth metals to the active metals, and (2) increasing the oxygen vacancies and mobility of active oxygen (i.e. free oxygen and lattice oxygen) by introducing alkaline earth metals in the support.

The modification of active metals by alkaline-earth metals (e.g. $\mathrm{Ca}, \mathrm{Mg}$ and $\mathrm{Sr}$ ) decreases the acidity of steam reforming catalysts, and induces a more favorable reaction pathway. It can also promote the catalytic activity by enhancing the nickel dispersion [198, 199]. However, the enhancement of supports by alkaline-earth metals showed much more complex mechanisms. Li et al. [79] synthesized nickel calcium aluminum catalysts $\left(\mathrm{Ni} / \mathrm{Ca}_{12} \mathrm{Al}_{14} \mathrm{O}_{33}\right)$ forsteam reforming of toluene in a fixed bed reactor. They found that even $1 \%$ of Ni loading catalyst showed an excellent performance in terms of catalytic activity, catalyst lifetime, resistance to carbon deposition and sulfur-tolerant ability. This was due to the presence of "free oxygen $\mathrm{O}_{2}{ }^{-}$and $\mathrm{O}_{2}{ }^{2-}$ " in the framework of mayenite, which was confirmed by the Raman spectra (Figure 16). Sekine et al. [200] investigated the effect of different alkaline-earth metals ( $\mathrm{Sr}, \mathrm{Ba}$ or $\mathrm{Ca}$ ) on the activity of a $\mathrm{Ni} / \mathrm{LaAlO}_{3}$ catalyst during steam reforming of toluene, and found that the catalyst with $30 \% \mathrm{La}$ 
substituted by $\mathrm{Sr}$ showed the highest catalytic performance with a toluene conversion of $58.2 \%$, a hydrogen selectivity of $48.4 \%$, and a carbon deposition amount of $57 \mathrm{mg} \cdot \mathrm{g} \cdot \mathrm{cat}^{-1}$. To demonstrate the promotion mechanism, the transient response tests using $\mathrm{H}_{2}{ }^{18} \mathrm{O}$ over $\mathrm{Ni} / \mathrm{LaAlO}_{3}, \mathrm{Ni} / \mathrm{Sr} /$ $\mathrm{LaAlO}_{3}$ and $\mathrm{Ni} / \mathrm{La}_{0.7} \mathrm{Sr}_{0.3} \mathrm{AlO}_{3-8}$ were conducted. The results revealed that the ${ }^{18} \mathrm{O}$ products were only detected over the $\mathrm{Ni} / \mathrm{La}_{0.7} \mathrm{Sr}_{0.3} \mathrm{AlO}_{3-\delta}$ catalyst derived from the redox of lattice oxygen in the catalyst and $\mathrm{H}_{2}{ }^{18} \mathrm{O}$. Therefore, the lattice oxygen in the $\mathrm{Sr}$ modified $\mathrm{Ni} / \mathrm{LaAlO}_{3}$ catalyst $\mathrm{Ni} / \mathrm{La}_{0.7} \mathrm{Sr}_{0.3} \mathrm{AlO}_{3-\delta}$ worked as an active oxygen compound to promote the reforming of toluene and the suppression of carbon deposition [201-203].

Oemar et al. [93] compared the activity of $\mathrm{Ni} / \mathrm{LaAlO}_{3}, \mathrm{Ni} / \mathrm{La}_{0.8} \mathrm{Sr}_{0.2} \mathrm{AlO}_{3}, \mathrm{Ni} / \mathrm{La}_{2} \mathrm{O}_{3}$, and $\mathrm{Ni} / \alpha-\mathrm{Al}_{2} \mathrm{O}_{3}$ catalysts that were prepared using a wet impregnation method for steam reforming of toluene. The results indicated that the $\mathrm{Ni} / \mathrm{La}_{0.8} \mathrm{Sr}_{0.2} \mathrm{AlO}_{3}$ catalyst showed the most superior catalytic performance in terms of the catalytic activity and coke resistance. The characterizations of the catalysts revealed that the superior catalytic performance of the $\mathrm{Ni} / \mathrm{La}_{0.8} \mathrm{Sr}_{0.2} \mathrm{AlO}_{3}$ catalyst should be attributed to the lattice distortion caused by $\mathrm{Sr}$ doping, since it produced higher concentrations of oxygen vacancies on the surface of the catalyst. Therefore, the activation energy of the migration of lattice oxygen was reduced, the mobility of lattice oxygen species was enhanced, and the adsorption abilities of gas phase oxygen species was improved [202, 203]. Besides, the influence of alkaline earth metal $\left(\mathrm{Mg}, \mathrm{Ca}\right.$, and $\mathrm{Sr}$ ) substitution to $\mathrm{LaNi}_{0.8} \mathrm{Fe}_{0.2} \mathrm{O}_{3}$ perovskite catalyst on steam reforming of toluene was investigated [204]. The catalytic activity decreased with the order of $\mathrm{La}_{0.8} \mathrm{Sr}_{0.2} \mathrm{Ni}_{0.8} \mathrm{Fe}_{0.2} \mathrm{O}_{3}$ (LSNFO) $>\mathrm{La}_{0.8} \mathrm{Ca}_{0.2} \mathrm{Ni}_{0.8} \mathrm{Fe}_{0.2} \mathrm{O}_{3}$ (LCNFO) $>$ $\mathrm{La}_{0.8} \mathrm{Mg}_{0.2} \mathrm{Ni}_{0.8} \mathrm{Fe}_{0.2} \mathrm{O}_{3}$ (LMNFO) catalyst. However, the amount of carbon deposition on the surface of the reacted catalyst showed an absolutely opposite order of LSNFO $<$ LCNFO $<$ LMNFO $<$ LNFO, as presented in Figure 17b. LSNFO was proved to be the most potential as for the catalytic activity and resistance to carbon deposition, owing to the increasing amount of active sites and lattice oxygen, as displayed in Figure 17a.

\section{$<$ Figure 16> \\ $<$ Figure 17>}

\subsubsection{Activation by alkali metals}

Alkali metals, such as $\mathrm{Na}$ and $\mathrm{K}$, are the representative impurities in biomass. They are easy to be volatilized and condensed with the produced tar during gasification process [205]. Therefore, alkali metals species were generally retained in the biomass-derived tar, and played a role in catalytic reduction of tar [206]. It was reported that alkali metals, especially K, could enhance hydrogen production from biomass pyrolysis or catalytic reforming of biomass-derived $\operatorname{tar}[4,14,89]$. The typical K-levels in the gas phase was around 0.01-5 ppmv (db) [207, 208].

Iwasa et al. [209] found that the addition of alkali metals into catalyst significantly enhanced the initial activity of a Ni-incorporated mesoporous smectite-like material (SM(Ni)) for steam reforming of acetic acid as a model compound of bio-oil. An activity order of $\mathrm{K}>\mathrm{Na}>$ $\mathrm{Rb}>\mathrm{Li}>\mathrm{Cs}$ was obtained (Figure 18a) and the $1.0 \mathrm{wt} \% \mathrm{~K}$-modified SM(Ni) catalyst exhibited the best performance for acetic conversion. This is because that the addition of $\mathrm{K}$ promoted the reduction of $\mathrm{Ni}$ species, thus more metallic $\mathrm{Ni}$ species were available for catalytic reactions. Consequently, the K-modified SM (Ni) catalyst showed a higher initial activity, which was gradually decreased due to deposition of carbon on the surface of reacted catalyst (Figure 18b). 
Akiyama et al. [210] observed that a cesium-doped $\mathrm{Ni} / \mathrm{ZrO}_{2}$ catalyst was more effective in promoting hydrogen formation and suppressing carbon deposition than the Li-, K-, La- and Ce-doped catalysts in steam reforming of ethanol. The catalytic mechanism of $\mathrm{Cs}_{0.2} \mathrm{Ni} / \mathrm{ZrO}_{2}$ was given by the pulse experiment using $\mathrm{H}_{2}{ }^{18} \mathrm{O}$ and TPD (temperature-programmed desorption) characterization, as indicated in Figure 19. It is indicated that the $\mathrm{Cs}_{0.2} \mathrm{Ni} / \mathrm{ZrO}_{2}$ was helpful to facilitate the dissociation of $\mathrm{H}_{2} \mathrm{O}$ to $2 \mathrm{H}$ and $\mathrm{O}$ atoms. In addition, the decomposition of $\mathrm{CH}_{3} \mathrm{CHO}$ to form hydrogen and $\mathrm{CO}_{2}$ through the $\mathrm{CH}_{3} \mathrm{CO}$ species was promoted. Furthermore, the TPD results showed that the $\mathrm{C}-\mathrm{H}$ breaking in the $\mathrm{CH}_{3} \mathrm{CO}$ species was enhanced in the presence of the Cs-doped $\mathrm{Ni} / \mathrm{ZrO}_{2}$ catalyst compared to the $\mathrm{Ni} / \mathrm{ZrO}_{2}$ catalyst. Guan et al. [62, $206,211]$ found that a small amount of alkali species such as potassium added in the biomass could be accumulated on the surface of catalysts with biomass-derived tar, and hence promoted significantly the catalytic activity of the regenerated catalyst. Krerkkaiwan et al. [212] confirmed that the char derived from co-pyrolysis of coal and giant leucaena wood exhibited a good catalytic steam reforming of tar because of the high surface area and the presence of alkali and alkaline earth metals (AAEM) on the char. The enhancement of alkali metals on catalytic activity was believed to be related to the catalytic functions of AAEM and the transfer of $\mathrm{OH}$ and $\mathrm{H}$ radicals from coal to biomass [213].

\section{$<$ Figure 18 $>$ \\ $<$ Figure 19>}

Potassium can not only affect the yields of gaseous, liquid and char products, but also can lead to the change of their compositions, especially the liquid compositions. It is obviously that potassium was benefical for the formation of low molecular weight compounds in biomass pyrolysis by reducing the amount of levoglucosan [214]. Wang et al. [215] reported that $\mathrm{K}_{2} \mathrm{CO}_{3}$ had a strong catalytic activity for the decomposition of hemicellulose, cellulose and lignin constituents. The addition of $\mathrm{K}_{2} \mathrm{CO}_{3}$ leaded to the decrease of liquid product yield and the increase of gaseous $\left(\mathrm{H}_{2}, \mathrm{CO}_{2}\right.$ and $\left.\mathrm{CO}\right)$ and char yields, which were caused by the promotion of secondary reactions of liquid products. With the addition of $17.7 \mathrm{wt} . \%$ of $\mathrm{K}_{2} \mathrm{CO}_{3}$, saccharides, aldehydes and alcohols were not formed, the yields of acids, furans and guaiacols were substantially reduced, and the yields of alkanes and phenols were increased.

Cosidering the effect of alkali metals on the catalytic activity of steam reforming process, there are different conclusions about the negative effect of alkali metals on hydrogen production from thermo-chemical conversion of biomass. For example, it was reported that the addition of alkali metals reduced the reforming activity of catalyst due to the loss of surface area that was caused by the sintering of alkali metals and clogging of wider pores [216]. Li et al. [217] exposed a Ni-based catalyst to different alkali salt vapors $\left(\mathrm{KCl}, \mathrm{K}_{2} \mathrm{SO}_{4}\right.$, and $\left.\mathrm{K}_{2} \mathrm{CO}_{3}\right)$ and subsequently the deactivation of reforming reaction was detected. Meanwhile, physical characterization revealed the severe loss of surface area of the catalyst. $\mathrm{K}_{2} \mathrm{SO}_{4}$ was expected to show the most deleterious effect due to the additional sulfur dosing. Although the addition of alkaline promoters caused the decrease in the catalytic activity due to thermal sintering, the resistance against deleterious carbon whisker and the long-term stability of the catalyst were simultaneously increased due to the adsorption of alkali metals [94, 218]. 


\section{Concluding remarks}

Biomass conversion into energy species, especially syngas, is of significant importance, since it can be used as an alternative substitution of the fossil energy for energy production. However, the formation of undesirable tar limits the utilization of syngas. The application of Ni-based catalysts in steam reforming of tar attracts increasing attention due to their high activity, low-cost and easy regeneration. Meanwhile, the further modification of conventional Ni-based catalysts is still essential due to the easy deactivation caused by coke deposition and the sintering of metal particles.

Thus, the modification methods of Ni-based steam reforming catalysts have been summarized in this manuscript, including the motivation of active metals, the addition of promoters, the enhancement of supporting materials and the modification of preparation methods. It will offer guidance for further research works on promoting the catalytic performance of conventional Ni-based catalysts. The detailed modification methods are suggested be conducted in the following aspects:

$>$ Motivation of the active metals by:

(i) alloying $\mathrm{Ni}$ with secondary metals, such as other transition metals ( $\mathrm{Fe}, \mathrm{Co}, \mathrm{Cu}, \mathrm{Mn}$, etc) to improve the oxygen adsorption ability, promote carbon gasification and increase the resistance to coke formation, and

(ii) enhancing the reducibility of $\mathrm{Ni}$ species and simultaneously increasing the dispersion of Ni metal particles by adding noble metals ( $\mathrm{Pt}, \mathrm{Pd}, \mathrm{Rh}, \mathrm{Ru}, \mathrm{Ir}, \mathrm{Au}$, etc.).

$>$ Addition of promoters by doping of:

(iii) rare earth metals $\left(\mathrm{La}_{2} \mathrm{O}_{3}, \mathrm{CeO}_{2}, \mathrm{Pr}_{6} \mathrm{O}_{11}, \mathrm{Sm}_{2} \mathrm{O}_{3}\right.$, etc.) with outstanding redox ability, in order to increase the metal-support interaction, the oxygen storage capacity of catalyst and further promote coke gasification;

(iv) alkaline-earth metals $(\mathrm{Mg}, \mathrm{Ca}, \mathrm{Sr}, \mathrm{Ba}$, etc.), with the purpose of promoting steam reforming reactions and decreasing the acidity of catalyst by the addition of alkaline earth metals to the active metals, and increasing oxygen vacancies and mobility of active oxygen by introducing alkaline earth metals in catalyst supports; and

(v) alkali metals (especially $\mathrm{K}$ ) for promoting the reduction of Ni species and increasing the basicity of catalysts.

$>$ Enhancement of supporting materials, by using:

(vi) rare-earth oxides due to the high oxygen storage capacity (OSC), oxygen mobility and strong metal-support interactions;

(vii) modified natural minerals (calcined olivine, dolomites, calcite, scallop shell) because of their high activity at high temperature, excellent $\mathrm{CO}_{2}$ adsorption ability, low cost, non-toxic and easy availability;

(viii) zeolites (SBA-15, ZSM-5, MCM-41, etc.) because of their well-defined pore structures, extremely high surface area, better thermal/hydrothermal stability, easy regeneration ability and higher confinement effect of their mesoporous structures; and

(ix) synthetic minerals (hydrotalcite-, palygorskite-, perovskite- and mayenite-like compounds) due to the formation of smaller metal nanoparticles, higher metal dispersion and stronger metal-support interaction.

$>$ Modification of preparation method, by: 
(x) selecting appropriate $\mathrm{Ni}$ precursors (nickel nitrate, nickel acetate and novel nickel precursors); and

(xi) optimizing the preparation procedure (co-precipitation, hydrothermal, sol-gel), calcined temperature, and $\mathrm{Ni} /$ promoter ratio, in order to obtain smaller metal nanoparticles, higher $\mathrm{Ni}$ dispersion and stronger metal-support interaction.

\section{Acknowledgement}

This study was financially supported by the Hebei Province Department of Education (Project No. BJ2017032), the Excellence Foundation of BUAA for PhD Students (Project No. 2017026), Science and Technology Project from Hebei Province (Project No. 16273709D), Natural Science Foundation of Hebei Province (Project No. E2016202361) and Key National Technology Development Project (Project No. 2016YFC0209202). In addition, the authors and publishers are grateful to the authors and publishers who have given permission for the use of copyright material identified in the text. In the cases where it has not been possible to identify the source of material used the publishers would welcome information from copyright owners.

\begin{tabular}{ll} 
Abbreviations \\
\hline Abbreviation & Full name \\
\hline RES & Renewable energy sources \\
GHGs & greenhouse gases \\
RIGES & Renewable intensive global energy scenario \\
DME & Dimethylether \\
PAHs & Polycyclic aromatic hydrocarbons \\
HMA & Hexamethylenetetramine \\
REOs & Rare earth oxides \\
WGSR & Water-gas shift reaction \\
NTP & Non-thermal plasma \\
OSC & Oxygen storage capacity \\
CS & Calcined scallop shell \\
OCs & Oxygen carriers \\
NFA & Nickel-iron alloy catalysts \\
1-MN & 1-methylnaphthalene \\
NM & Noble metals \\
AIMD & ab initio molecular dynamic \\
SM(Ni) & Ni-incorporated mesoporous smectite-like material \\
AAEM & Alkali and alkaline earth metals \\
HTlcs & Hydrotalcite-like compounds \\
SEM & Scanning electron microscope \\
XRD & X-Ray powder diffraction \\
TPR & Temperature-programmed reduction \\
TPD & Temperature programmed desorption \\
TGA & Thermogravimetry \\
XPS & X-ray photoelectron spectroscopy \\
\hline & \\
&
\end{tabular}




\section{References}

[1] Panwar NL, Kaushik SC, Kothari S. Role of renewable energy sources in environmental protection: A review. Renewable \& Sustainable Energy Reviews. 2011;15:1513-24.

[2] Field CB, Campbell JE, Lobell DB. Biomass energy: the scale of the potential resource. Trends in Ecology \& Evolution. 2008;23:65-72.

[3] Herbert GMJ, Krishnan AU. Quantifying environmental performance of biomass energy. Renewable \& Sustainable Energy Reviews. 2016;59:292-308.

[4] Han J, Kim H. The reduction and control technology of tar during biomass gasification/pyrolysis: An overview. Renewable \& Sustainable Energy Reviews. 2008;12:397-416.

[5] Hall DO, Hüttl RF. Biomass energy in industrialised countries-a view of the future. Forest Ecology \& Management. 1997;91:17-45.

[6] Zhao ZY, Zuo J, Fan LL, Zillante G. Impacts of renewable energy regulations on the structure of power generation in China-A critical analysis. Renewable Energy. 2011;36:24-30.

[7] Mckendry P. Energy production from biomass (Part 1): Overview of biomass. Bioresource Technology. 2002;83:37.

[8] Vassilev SV, Baxter D, Vassileva CG. An overview of the behaviour of biomass during combustion: Part I. Phase-mineral transformations of organic and inorganic matter. Fuel. 2013;112:391-449.

[9] Lasa HD, Salaices E, Mazumder J, Lucky R. Catalytic Steam Gasification of Biomass: Catalysts, Thermodynamics and Kinetics. Chemical Reviews. 2011;111:5404-33.

[10] Dufour A, Masson E, Girods P, Rogaume Y, Zoulalian A. Evolution of aromatic tar composition in relation to methane and ethylene from biomass pyrolysis-gasification. Energy \& Fuels. 2011;25:41829.

[11] Shen Y, Zhao P, Shao Q, Ma D, Takahashi F, Yoshikawa K. In-situ catalytic conversion of tar using rice husk char-supported nickel-iron catalysts for biomass pyrolysis/gasification. Applied Catalysis B Environmental. 2014;s152-153:140-51.

[12] Esen M, Yuksel T. Experimental evaluation of using various renewable energy sources for heating a greenhouse. Energy \& Buildings. 2013;65:340-51.

[13] Sartipi S, Parashar K, Valero-Romero MJ, Santos VP, Linden BVD, Makkee M, et al. Hierarchical H-ZSM-5-supported cobalt for the direct synthesis of gasoline-range hydrocarbons from syngas: Advantages, limitations, and mechanistic insight. Journal of Catalysis. 2013;305:179-90.

[14] Anis S, Zainal ZA. Tar reduction in biomass producer gas via mechanical, catalytic and thermal methods: A review. Renewable \& Sustainable Energy Reviews. 2011;15:2355-77.

[15] Guan G, Kaewpanha M, Hao X, Abudula A. Catalytic steam reforming of biomass tar: Prospects and challenges. Renewable \& Sustainable Energy Reviews. 2016;58:450-61.

[16] Mohan D, Pittman CU, Steele PH. Pyrolysis of wood/biomass for bio-oil: A critical review. Energy \& Fuels. 2006;20:848--89.

[17] Blasi CD. Modeling chemical and physical processes of wood and biomass pyrolysis. Progress in Energy \& Combustion Science. 2008;34:47-90.

[18] Sun Y, Liu L, Wang Q, Yang X, Tu X. Pyrolysis products from industrial waste biomass based on a neural network model. Journal of Analytical \& Applied Pyrolysis. 2016;120:94-102.

[19] Evans RJ, Milne TA. Molecular characterization of the pyrolysis of biomass. Energy \& Fuels. 1987;1:123-37.

[20] Palma CF. Modelling of tar formation and evolution for biomass gasification: A review. Applied Energy. 2013;111:129-41. 
[21] Richardson Y, Blin J, Julbe A. A short overview on purification and conditioning of syngas produced by biomass gasification: Catalytic strategies, process intensification and new concepts. Progress in Energy \& Combustion Science. 2012;38:765-81.

[22] Bulushev DA, Ross JRH. Catalysis for conversion of biomass to fuels via pyrolysis and gasification: A review. Catalysis Today. 2011;171:1-13.

[23] Ashok J, Kawi S. Steam reforming of toluene as a biomass tar model compoundover $\mathrm{CeO}_{2}$ promoted $\mathrm{Ni} / \mathrm{CaO}-\mathrm{Al}_{2} \mathrm{O}_{3}$ catalytic systems. International Journal of Hydrogen Energy. 2013;38:13938-49.

[24] Zhu F, Li X, Zhang H, Wu A, Yan J, Ni M, et al. Destruction of toluene by rotating gliding arc discharge. Fuel. 2016;176:78-85.

[25] Tao K, Ohta N, Liu G, Yoneyama Y, Wang T, Tsubaki N. Plasma enhanced catalytic reforming of biomass tar model compound to syngas. Fuel. 2013;104:53-7.

[26] Liu S, Mei D, Wang L, Tu X. Steam reforming of toluene as biomass tar model compound in a gliding arc discharge reactor. Chemical Engineering Journal. 2016;307:793-802.

[27] Paethanom A, Nakahara S, Kobayashi M, Prawisudha P, Yoshikawa K. Performance of tar removal by absorption and adsorption for biomass gasification. Fuel Processing Technology. 2012;104:144-54.

[28] Phuphuakrat T, Namioka T, Yoshikawa K. Absorptive removal of biomass tar using water and oily materials. Bioresource Technology. 2011;102:543-9.

[29] Laurence LC, Ashenafi D. Syngas treatment unit for small scale gasification-Application to IC engine gas quality requirement. Journal of Applied Fluid Mechanics. 2012;5:95-103.

[30] Shen Y, Wang J, Ge X, Chen M. By-products recycling for syngas cleanup in biomass pyrolysis An overview. Renewable \& Sustainable Energy Reviews. 2016;59:1246-68.

[31] Chung WC, Chang MB. Review of catalysis and plasma performance on dry reforming of $\mathrm{CH} 4$ and possible synergistic effects. Renewable \& Sustainable Energy Reviews. 2016;62:13-31.

[32] Li C, Suzuki K. Resources, properties and utilization of tar. Resources Conservation \& Recycling. 2010;54:905-15.

[33] Aravind PV, Jong WD. Evaluation of high temperature gas cleaning options for biomass gasification product gas for solid oxide fuel cells. Progress in Energy \& Combustion Science. 2012;38:737-64.

[34] Richardson Y, Blin J, Julbe A. A short overview on purification and conditioning of syngas produced by biomass gasification: Catalytic strategies, process intensification and new concepts. Progress in Energy \& Combustion Science. 2012;38:765-81.

[35] Xu C, Donald J, Byambajav E, Ohtsuka Y. Recent advances in catalysts for hot-gas removal of tar and NH from biomass gasification. Fuel. 2010;89:1784-95.

[36] Shen Y, Yoshikawa K. Recent progresses in catalytic tar elimination during biomass gasification or pyrolysis - A review. Renewable \& Sustainable Energy Reviews. 2013;21:371-92.

[37] Palma CF. Model for biomass gasification including tar formation and evolution. Energy \& Fuels. 2013;27:2693-702.

[38] Palma CF. Modelling of tar formation and evolution for biomass gasification: A review. Applied Energy. 2013;111:129-41.

[39] Cypres R, Bettens B. Mecanismes de fragmentation pyrolytique du phenol et des cresols. Tetrahedron. 1974;30:1253-60.

[40] Ahrenfeldt J, Egsgaard H, Stelte W, Thomsen T, Henriksen UB. The influence of partial oxidation 
mechanisms on tar destruction in TwoStage biomass gasification. Fuel. 2013;112:662-80.

[41] Sharma RK, Hajaligol MR. Effect of pyrolysis conditions on the formation of polycyclic aromatic hydrocarbons (PAHs) from polyphenolic compounds. Journal of Analytical \& Applied Pyrolysis. 2003;66:123-44.

[42] Georgios Taralas, And MGK, Kakatsios X. Modeling the thermal destruction of toluene $\left(\mathrm{C}_{7} \mathrm{H}_{8}\right)$ as tar-related species for fuel gas cleanup. Energy \& Fuels. 2003;17:329-37.

[43] Gai C, Dong Y, Yang S, Zhang Z, Liang J, Li J. Thermal decomposition kinetics of light polycyclic aromatic hydrocarbons as surrogate biomass tar. Rsc Advances. 2016;6.

[44] Karnjanakom S, Guan GQ, Asep B, Xiao D, Hao XG, Samart C, et al. Catalytic steam reforming of tar derived from steam gasification of sunflower stalk over ethylene glycol assisting prepared Ni/MCM-41. Energy Conversion \& Management. 2015;98:359-68.

[45] Guan GQ, Kaewpanha M, Hao XG, Abudula A. Catalytic steam reforming of biomass tar: prospects and challenges. Renewable \& Sustainable Energy Reviews. 2016;58:450-61.

[46] Eliott RM, Nogueira MFM, Sobrinho ASS, Couto BAP, Maciel HS, Lacava PT. Tar reforming under a microwave plasma torch. Energy \& Fuels. 2013;27:1174-81.

[47] Ammendola P, Lisi L, Ruoppolo G. Partial oxidation of tar into syngas over Rh-based catalysts. Combustion Science and Technology. 2014;186:563-73.

[48] Ma M, Müller M, Richter J, Kriegel R, Böhning D, Beckmann M, et al. Investigation of combined catalyst and oxygen carrier systems for the partial oxidation of naphthalene as model tar from biomass gasification. Biomass \& Bioenergy. 2013;53:65-71.

[49] Chen Y, Luo Y, Wu W, Su Y. Experimental investigation on tar formation and destruction in a lab-scale two-stage reactor. Energy \& Fuels. 2009;23:4659-67.

[50] Nair SA, Yan K, Pemen AJM, Heesch EJMV, Ptasinski KJ, Drinkenburg AAH. Tar removal from biomass derived fuel gas by pulsed corona discharges: Chemical kinetic study II. Industrial \& Engineering Chemistry Research. 2005;44:págs. 1734-41.

[51] Nair SA, Pemen AJM, Yan K, Gompel FMV, Leuken HEMV, Heesch EJMV, et al. Tar removal from biomass-derived fuel gas by pulsed corona discharges. Fuel Processing Technology. 2003;84:161-73.

[52] Guo YF, Ye DQ, Chen KF, He JC. Toluene removal by a DBD-type plasma combined with metal oxides catalysts supported by nickel foam. Catalysis Today. 2007;126:328-37.

[53] Karatum O, Deshusses MA. A comparative study of dilute VOCs treatment in a non-thermal plasma reactor. Chemical Engineering Journal. 2016;294:308-15.

[54] Świerczyński D, Libs S, Courson C, Kiennemann A. Steam reforming of tar from a biomass gasification process over Ni/olivine catalyst using toluene as a model compound. Applied Catalysis B Environmental. 2007;74:211-22.

[55] Wolfesbergerschwabl U, Aigner I, Hofbauer H. Mechanism of tar generation during fluidized bed gasification and low temperature pyrolysis. Industrial \& Engineering Chemistry Research. 2012;51:13001-7.

[56] Ashok J, Kawi S. Nickel-iron alloy supported over iron-alumina catalysts for steam reforming of biomass tar model compound. Acs Catalysis. 2014;4:289-301.

[57] Gao N, Wang X, Li A, Wu C, Yin Z. Hydrogen production from catalytic steam reforming of benzene as tar model compound of biomass gasification. Fuel Processing Technology. 2016;148:380-7.

[58] Wang L, Li D, Koike M, Koso S, Nakagawa Y, Xu Y, et al. Catalytic performance and characterization of $\mathrm{Ni}-\mathrm{Fe}$ catalysts for the steam reforming of tar from biomass pyrolysis to synthesis 
gas. Applied Catalysis A General. 2011;392:248-55.

[59] Yung MM, Jablonski WS, Magrinibair KA. Review of catalytic conditioning of biomass-derived syngas. Energy \& Fuels. 2009;23:1874-87.

[60] Michel R, Rapagnà S, Marcello MD, Burg P, Matt M, Courson C, et al. Catalytic steam gasification of Miscanthus $\mathrm{X}$ giganteus in fluidised bed reactor on olivine based catalysts. Fuel Processing Technology. 2011;92:1169-77.

[61] Sutton D, Kelleher B, Ross JRH. Review of literature on catalysts for biomass gasification. Fuel Processing Technology. 2001;73:155-73.

[62] Guan G, Chen G, Kasai Y, Lim EWC, Hao X, Kaewpanha M, et al. Catalytic steam reforming of biomass tar over iron- or nickel-based catalyst supported on calcined scallop shell. Applied Catalysis B Environmental. 2012;S115-116:159-68.

[63] Wang L, Hisada Y, Koike M, Li D, Watanabe H, Nakagawa Y, et al. Catalyst property of Co-Fe alloy particles in the steam reforming of biomass tar and toluene. Applied Catalysis B Environmental. 2012;s 121-122:95-104.

[64] Ammendola P, Cammisa E, Chirone R, Lisi L, Ruoppolo G. Effect of sulphur on the performance of $\mathrm{Rh}-\mathrm{LaCoO}_{3}$ based catalyst for tar conversion to syngas. Applied Catalysis B Environmental. 2012;S113-114:11-8.

[65] Virginie M, Courson C, Niznansky D, Chaoui N, Kiennemann A. Characterization and reactivity in toluene reforming of a Fe/olivine catalyst designed for gas cleanup in biomass gasification. Applied Catalysis B Environmental. 2010;101:90-100.

[66] Mei D, Lebarbier VM, Rousseau R, Glezakou VA, Albrecht KO, Kovarik L, et al. Comparative investigation of benzene steam reforming over spinel supported $\mathrm{Rh}$ and Ir catalysts. Acs Catalysis. 2013;3:1133-43.

[67] Nakamura K, Miyazawa T, Sakurai T, Miyao T, Naito S, Begum N, et al. Promoting effect of MgO addition to Pt $/ \mathrm{Ni} / \mathrm{CeO}_{2} / \mathrm{Al}_{2} \mathrm{O}_{3}$ in the steam gasification of biomass. Applied Catalysis B Environmental. 2009;86:36-44.

[68] Torres W, Pansare SS, Jr JGG. Hot gas removal of tars, ammonia, and hydrogen sulfide from biomass gasification gas. Catalysis Reviews. 2007;49:407-56.

[69] Ahmed S, Aitani A, Rahman F, Al-Dawood A, Al-Muhaish F. Decomposition of hydrocarbons to hydrogen and carbon. Applied Catalysis A General. 2009;359:1-24.

[70] Park HJ, Park SH, Sohn JM, Park J, Jeon JK, Kim SS, et al. Steam reforming of biomass gasification tar using benzene as a model compound over various Ni supported metal oxide catalysts. Bioresource Technology. 2010;101 Suppl 1:S101.

[71] Quitete CPB, Bittencourt RCP, Souza MMVM. Steam reforming of tar using toluene as a model compound with nickel catalysts supported on hexaaluminates. Applied Catalysis A General. 2014;478:234-40.

[72] Srinakruang J, Sato K, Vitidsant T, Fujimoto K. A highly efficient catalyst for tar gasification with steam. Catalysis Communications. 2005;6:437-40.

[73] Wang TJ, Chang J, Wu CZ, Fu Y, Chen Y. The steam reforming of naphthalene over a nickel-dolomite cracking catalyst. Biomass \& Bioenergy. 2005;28:508-14.

[74] Magrini-Bair KA, Czernik S, French R, Parent YO, Chornet E, Dayton DC, et al. Fluidizable reforming catalyst development for conditioning biomass-derived syngas. Applied Catalysis A General. 2007;318:199-206.

[75] Zhang R, Brown RC, Suby A, Cummer K. Catalytic destruction of tar in biomass derived producer 
gas. Energy Conversion \& Management. 2004;45:995-1014.

[76] Coll R, Salvadó J, Farriol X, Montané D. Steam reforming model compounds of biomass gasification tars: conversion at different operating conditions and tendency towards coke formation. Fuel Processing Technology. 2001;74:19-31.

[77] Laosiripojana N, Assabumrungrat S. Catalytic steam reforming of ethanol over high surface area $\mathrm{CeO}_{2}$ : The role of $\mathrm{CeO}_{2}$ as an internal pre-reforming catalyst. Applied Catalysis B Environmental. 2006;66:29-39.

[78] Artetxe M, Alvarez J, Nahil MA, Olazar M, Williams PT. Steam reforming of different biomass tar model compounds over $\mathrm{Ni} / \mathrm{Al}_{2} \mathrm{O}_{3}$ catalysts. Energy Conversion \& Management. 2017;136:119-26.

[79] Li C, Hirabayashi D, Suzuki K. A crucial role of $\mathrm{O}^{2-}$ and $\mathrm{O}_{2}{ }^{2-}$ on mayenite structure for biomass tar steam reforming over Ni/Ca ${ }_{12} \mathrm{Al}_{14} \mathrm{O}_{33}$. Applied Catalysis B Environmental. 2009;88:351-60.

[80] Sehested J. Four challenges for nickel steam-reforming catalysts. Catalysis Today. 2006;111:103-10.

[81] Melo F, Morlanés N. Naphtha steam reforming for hydrogen production. Catalysis Today. 2005;s 107-108:458-66.

[82] Nikolla E, Schwank J, Linic S. Comparative study of the kinetics of methane steam reforming on supported Ni and $\mathrm{Sn} / \mathrm{Ni}$ alloy catalysts: The impact of the formation of Ni alloy on chemistry. Journal of Catalysis. 2009;263:220-7.

[83] Zhu X, Huo P, Zhang YP, Cheng DG, Liu CJ. Structure and reactivity of plasma treated Ni/ $\mathrm{Al}_{2} \mathrm{O}_{3}$ catalyst for $\mathrm{CO}_{2}$ reforming of methane. Applied Catalysis B Environmental. 2008;81:132-40.

[84] Achouri IE, Abatzoglou N, Fauteux-Lefebvre C, Braidy N. Diesel steam reforming: Comparison of two nickel aluminate catalysts prepared by wet-impregnation and co-precipitation. Catalysis Today. 2013;207:13-20.

[85] Wang H, Miller JT, Shakouri M, Xi C, Wu T, Zhao H, et al. XANES and EXAFS studies on metal nanoparticle growth and bimetallic interaction of Ni-based catalysts for $\mathrm{CO}_{2}$ reforming of $\mathrm{CH}_{4}$. Catalysis Today. 2013;207:3-12.

[86] Li D, Koike M, Wang L, Nakagawa Y, Xu Y, Tomishige K. Regenerability of hydrotalcite derived nickel-iron alloy nanoparticles for syngas production from biomass tar. Chemsuschem. 2014;7:510-22.

[87] Koike M, Li D, Watanabe H, Nakagawa Y, Tomishige K. Comparative study on steam reforming of model aromatic compounds of biomass tar over $\mathrm{Ni}$ and $\mathrm{Ni}-\mathrm{Fe}$ alloy nanoparticles. Applied Catalysis A General. 2015;506:151-62.

[88] Li D, Lu M, Aragaki K, Koike M, Nakagawa Y, Tomishige K. Characterization and catalytic performance of hydrotalcite-derived $\mathrm{Ni}-\mathrm{Cu}$ alloy nanoparticles catalysts for steam reforming of 1-methylnaphthalene. Applied Catalysis B Environmental. 2016;192:171-81.

[89] Dong HH, Lee R, Hwang JH, Sohn JM. The effect of addition of Ca, K and Mn over Ni-based catalyst on steam reforming of toluene as model tar compound. Catalysis Today. 2016;265:95-102.

[90] Chen J, Tamura M, Nakagawa Y, Okumura K, Tomishige K. Promoting effect of trace Pd on hydrotalcite-derived $\mathrm{Ni} / \mathrm{Mg} / \mathrm{Al}$ catalyst in oxidative steam reforming of biomass tar. Applied Catalysis B Environmental. 2015;179:412-21.

[91] Zhang R, Wang H, Hou X. Catalytic reforming of toluene as tar model compound: Effect of Ce and Ce-Mg promoter using Ni/olivine catalyst. Chemosphere. 2014;97:40-6.

[92] Garbarino G, Wang C, Valsamakis I, Chitsazan S, Riani P, Finocchio E, et al. A study of Ni/ $\mathrm{Al}_{2} \mathrm{O}_{3}$ and $\mathrm{Ni}-\mathrm{La} / \mathrm{Al}_{2} \mathrm{O}_{3}$ catalysts for the steam reforming of ethanol and phenol. Applied Catalysis $\mathrm{B}$ 
Environmental. 2015;s 174-175:21-34.

[93] Oemar U, Ming LA, Yin CC, Hidajat K, Kawi S-. Role of lattice oxygen in oxidative steam reforming of toluene as a tar model compound over $\mathrm{Ni} / \mathrm{La}_{0.8} \mathrm{Sr}_{0.2} \mathrm{AlO}_{3}$ catalyst. Catalysis Science \& Technology. 2015;5:3585-97.

[94] Seung-Hoon K, Jae-Sun J, Yang EH, Kwan-Young L, Ju MD. Hydrogen production by steam reforming of biomass-derived glycerol over Ni-based catalysts. Catalysis Today. 2014;228:145-51.

[95] Liu H, Chen T, Chang D, Chen D, Kong D, Zou X, et al. Effect of preparation method of palygorskite-supported Fe and Ni catalysts on catalytic cracking of biomass tar. Chemical Engineering Journal. 2012;188:108-12.

[96] Blanco PH, Wu C, Onwudili JA, Williams PT. Characterization and evaluation of $\mathrm{Ni} / \mathrm{SiO}_{2}$ catalysts for hydrogen production and tar reduction from catalytic steam pyrolysis-reforming of refuse derived fuel. Applied Catalysis B Environmental. 2013;S134-135:238-50.

[97] Laosiripojana N, Sutthisripok W, Charojrochkul S, Assabumrungrat S. Development of Ni-Fe bimetallic based catalysts for biomass tar cracking/reforming: Effects of catalyst support and co-fed reactants on tar conversion characteristics. Fuel Processing Technology. 2014;127:26-32.

[98] Wu G, Zhang C, Li S, Han Z, Wang T, Ma X, et al. Hydrogen production via glycerol steam reforming over $\mathrm{Ni} / \mathrm{Al}_{2} \mathrm{O}_{3}$ : Influence of nickel precursors. Acs Sustainable Chemistry \& Engineering. 2013;1:1052-62.

[99] Álvarez-Rodríguez J, Cerro-Alarcón M, Guerrero-Ruiz A, Rodríguez-Ramos I, Arcoya A. Effect of nickel precursor and the copper addition on the surface properties of $\mathrm{Ni} / \mathrm{KL}$-supported catalysts for selective hydrogenation of citral. Applied Catalysis A General. 2008;348:241-50.

[100] Li F, Yi X, Fang W. Effect of organic nickel precursor on the reduction performance and hydrogenation activity of $\mathrm{Ni} / \mathrm{Al}_{2} \mathrm{O}_{3}$ catalysts. Catalysis Letters. 2009;130:335-40.

[101] He S, Mei Z, Liu N, Zhang L, Lu J, Li X, et al. Ni/SBA-15 catalysts for hydrogen production by ethanol steam reforming: Effect of nickel precursor. International Journal of Hydrogen Energy. 2017;42:14429-38.

[102] Hyunju P, Sunghoon P, Jungmin S, Junhong P, Jongki J, Seungsoo K, et al. Steam reforming of biomass gasification tar using benzene as a model compound over various $\mathrm{Ni}$ supported metal oxide catalysts. Bioresource Technology. 2010;101 Suppl 1:S101.

[103] Eric M, Che M, Jiř Č, iacute, Arnošt Z. Nickel(II) nitrate vs. acetate:influence of the precursor on the structure and reducibility of Ni/MCM - 41 and Ni/Al - MCM - 41 catalysts. Chemcatchem. 2010;2:413-22.

[104] He S, Zheng X, Mo L, Yu W, Wang H, Luo Y. Characterization and catalytic properties of $\mathrm{Ni} / \mathrm{SiO}_{2}$ catalysts prepared with nickel citrate as precursor. Materials Research Bulletin. 2014;49:108-13.

[105] Li W, Zhao Z, Guo X, Wang G. Employing a nickel - containing supramolecular framework as $\mathrm{Ni}$ precursor for synthesizing robust supported $\mathrm{Ni}$ catalysts for dry reforming of methane. Chemcatchem. 2016;8:2939-52.

[106] Baktash E, Littlewood P, Pfrommer J, Schomäcker R, Driess M, Thomas A. Controlled formation of nickel oxide nanoparticles on mesoporous silica using molecular $\mathrm{Ni}_{4} \mathrm{O}_{4}$ clusters as precursors: enhanced catalytic performance for dry reforming of methane. Chemcatchem. 2015;7:1280-4.

[107] Kathiraser Y, Ashok J, Kawi S. Synthesis and evaluation of highly dispersed SBA-15 supported $\mathrm{Ni}-\mathrm{Fe}$ bimetallic catalysts for steam reforming of biomass derived tar reaction. Catalysis Science \& Technology. 2016;6:480-6. 
[108] Nahar G, Dupont V, Twigg MV, Dvininov E. Feasibility of hydrogen production from steam reforming of biodiesel (FAME) feedstock on Ni-supported catalysts. Applied Catalysis B Environmental. 2015;168-169:228-42.

[109] Baudouin D, Szeto KC, Laurent P, De MA, Fenet B, Veyre L, et al. Nickel-silicide colloid prepared under mild conditions as a versatile Ni precursor for more efficient $\mathrm{CO}_{2}$ reforming of $\mathrm{CH}_{4}$ catalysts. Journal of the American Chemical Society. 2012;134:20624.

[110] Wang T, Ma H, Zeng L, Li D, Tian H, Xiao S, et al. Highly loaded Ni-based catalysts for low temperature ethanol steam reforming. Nanoscale. 2016;8:10177-87.

[111] Luo X, Hong Y, Wang F, Hao S, Pang C, Lester E, et al. Development of nano $\mathrm{Ni}_{\mathrm{x}} \mathrm{Mg}_{\mathrm{y}} \mathrm{O}$ solid solutions with outstanding anti-carbon deposition capability for the steam reforming of methanol. Applied Catalysis B Environmental. 2016;194:84-97.

[112] Ashok J, Kathiraser Y, Ang ML, Kawi S. Ni and/or Ni-Cu alloys supported over $\mathrm{SiO}_{2}$ catalysts synthesized via phyllosilicate structures for steam reforming of biomass tar reaction. Catalysis Science \& Technology. 2015;5:4398-409.

[113] Han SJ, Bang Y, Yoo J, Seo JG, Song IK. Hydrogen production by steam reforming of ethanol over mesoporous $\mathrm{Ni}-\mathrm{Al}_{2} \mathrm{O}_{3}-\mathrm{ZrO}_{2}$ xerogel catalysts: Effect of nickel content. International Journal of Hydrogen Energy. 2013;38:8285-92.

[114] Wang L, Li D, Koike M, Watanabe H, Xu Y, Nakagawa Y, et al. Catalytic performance and characterization of Ni-Co catalysts for the steam reforming of biomass tar to synthesis gas. Fuel. 2013;112:654-61.

[115] Sokolov S, Kondratenko EV, Pohl MM, Rodemerck U. Effect of calcination conditions on time on-stream performance of $\mathrm{Ni} / \mathrm{La}_{2} \mathrm{O}_{3}-\mathrm{ZrO}_{2}$ in low-temperature dry reforming of methane. International Journal of Hydrogen Energy. 2013;38:16121-32.

[116] Jafarbegloo M, Tarlani A, Mesbah AW, Muzart J, Sahebdelfar S. NiO-MgO solid solution prepared by sol-gel method as precursor for $\mathrm{Ni} / \mathrm{MgO}$ methane dry reforming catalyst: Effect of calcination temperature on catalytic performance. Catalysis Letters. 2015;146:1-11.

[117] Ashok J, Kawi S. Nickel-iron alloy supported over iron-alumina catalysts for steam reforming of biomass tar model compound. Acs Catalysis. 2014;4:289-301.

[118] Oemar U, Ang M, Hidajat K, Kawi S. Enhancing performance of $\mathrm{Ni} / \mathrm{La}_{2} \mathrm{O}_{3}$ catalyst by Sr-modification for steam reforming of toluene as model compound of biomass tar. Rsc Advances. 2015;5:17834-42.

[119] Li D, Koike M, Chen J, Nakagawa Y, Tomishige K. Preparation of Ni-Cu/Mg/Al catalysts from hydrotalcite-like compounds for hydrogen production by steam reforming of biomass tar. International Journal of Hydrogen Energy. 2014;39:10959-70.

[120] Koike M, Li D, Nakagawa Y, Tomishige K. A highly active and coke-resistant steam reforming catalyst comprising uniform nickel-iron alloy nanoparticles. Chemsuschem. 2012;5:2312.

[121] Li D, Koike M, Wang L, Nakagawa Y, Xu Y, Tomishige K. Regenerability of hydrotalcite-derived nickel-iron alloy nanoparticles for syngas production from biomass tar. Chemsuschem. 2014;7:510-22.

[122] Dong L, Wu C, Ling H, Shi J, Williams PT, Huang J. Promoting hydrogen production and minimizing catalyst deactivation from the pyrolysis-catalytic steam reforming of biomass on nanosized $\mathrm{NiZnAlO}_{\mathrm{x}}$ catalysts. Fuel. 2017;188:610-20.

[123] Jafarbegloo M, Tarlani A, Mesbah AW, Muzart J, Sahebdelfar S. NiO-MgO solid solution prepared by sol-gel method as precursor for $\mathrm{Ni} / \mathrm{MgO}$ methane dry reforming catalyst: Effect of 
calcination temperature on catalytic performance. Catalysis Letters. 2015;146:1-11.

[124] Garbarino G, Lagazzo A, Riani P, Busca G. Steam reforming of ethanol-phenol mixture on $\mathrm{Ni} / \mathrm{Al}_{2} \mathrm{O}_{3}$ : Effect of $\mathrm{Ni}$ loading and sulphur deactivation. Applied Catalysis B Environmental. 2013;129:460-72.

[125] Chen T, Liu H, Shi P, Chen D, Song L, He H, et al. $\mathrm{CO}_{2}$ reforming of toluene as model compound of biomass tar on Ni/Palygorskite. Fuel. 2013;107:699-705.

[126] Park HJ, Park SH, Sohn JM, Park J, Jeon JK, Kim SS, et al. Steam reforming of biomass gasification tar using benzene as a model compound over various Ni supported metal oxide catalysts. Bioresource Technology. 2010;101:S101-S3.

[127] Wu C, Wang Z, Dupont V, Huang J, Williams PT. Nickel-catalysed pyrolysis/gasification of biomass components. Journal of Analytical \& Applied Pyrolysis. 2013;99:143-8.

[128] Wu C, Wang L, Williams PT, Shi J, Huang J. Hydrogen production from biomass gasification with Ni/MCM-41 catalysts: Influence of $\mathrm{Ni}$ content. Applied Catalysis B Environmental. 2011;108:6-13.

[129] Wu C, Wang Z, Williams PT, Huang J. Renewable hydrogen and carbon nanotubes from biodiesel waste glycerol. Scientific Reports. 2013;3:2742.

[130] Shen Y. Chars as carbonaceous adsorbents/catalysts for tar elimination during biomass pyrolysis or gasification. Renewable \& Sustainable Energy Reviews. 2015;43:281-95.

[131] Wang K, Dou B, Jiang B, Zhang Q, Li M, Chen H, et al. Effect of support on hydrogen production from chemical looping steam reforming of ethanol over Ni-based oxygen carriers. International Journal of Hydrogen Energy. 2016;41:17334-47.

[132] Song H, Ozkan US, Mirkelamoglu B. Effect of cobalt precursor on the performance of ceria-supported cobalt catalysts for ethanol steam reforming. Applied Catalysis A General. 2010;382:58-64.

[133] Salehi E, Azad FS, Harding T, Abedi J. Production of hydrogen by steam reforming of bio-oil over $\mathrm{Ni} / \mathrm{Al}_{2} \mathrm{O}_{3}$ catalysts: Effect of addition of promoter and preparation procedure. Fuel Processing Technology. 2011;92:2203-10.

[134] Li J, Yan R, Xiao B, Liang DT, Du L. Development of nano-NiO/ $/ \mathrm{Al}_{2} \mathrm{O}_{3}$ catalyst to be used for tar removal in biomass gasification. Environmental Science \& Technology. 2008;42:6224.

[135] Li CS, Hirabayashi D, Suzuki K, Lee JS, Saka S. Steam reforming of biomass tar producing $\mathrm{H}_{2}$-rich gases over Ni/MgO${ }_{x} / \mathrm{CaO}_{1-\mathrm{x}}$ catalyst. Bioresource Technology. 2010;101:S97-S100.

[136] Karim AM, Su Y, Engelhard MH, King DL, Wang Y. Catalytic Roles of $\mathrm{Co}^{0}$ and $\mathrm{Co}^{2+}$ during Steam Reforming of Ethanol on $\mathrm{Co} / \mathrm{MgO}$ Catalysts. Acs Catalysis. 2011;1:279-86.

[137] Rownaghi AA, Huhnke RL. Producing hydrogen-rich gases by steam reforming of syngas tar over $\mathrm{CaO} / \mathrm{MgO} / \mathrm{NiO}$ catalysts. Acs Sustainable Chemistry \& Engineering. 2013;1:80-6.

[138] Xu W, Liu Z, Johnstonpeck AC, Senanayake SD, Zhou G, Stacchiola D, et al. Steam reforming of ethanol on $\mathrm{Ni} / \mathrm{CeO}_{2}$ : Reaction pathway and interaction between $\mathrm{Ni}$ and the $\mathrm{CeO}_{2}$ support. Acs Catalysis. 2013;3:975-84.

[139] Cai W, Wang F, Daniel C, Veen ACV, Schuurman Y, Descorme C, et al. Oxidative steam reforming of ethanol over $\mathrm{Ir} / \mathrm{CeO}_{2}$ catalysts: A structure sensitivity analysis. Journal of Catalysis. 2012;286:137-52.

[140] Soykal II, Sohn H, Ozkan US. Effect of support particle size in steam reforming of ethanol over $\mathrm{Co} / \mathrm{CeO}_{2}$ catalysts. Acs Catalysis. 2013;2:2335-48.

[141] Mondal T, Pant KK, Dalai AK. Mechanistic kinetic modeling of oxidative steam reforming of 
bioethanol for hydrogen production over $\mathrm{Rh}-\mathrm{Ni} / \mathrm{CeO}_{2}-\mathrm{ZrO}_{2}$ catalyst. Industrial \& Engineering Chemistry Research. 2016;55:86-98.

[142] Carvalho FLS, Asencios YJO, Rego AMB, Assaf EM. Hydrogen production by steam reforming of ethanol over $\mathrm{Co}_{3} \mathrm{O}_{4} / \mathrm{La}_{2} \mathrm{O}_{3} / \mathrm{CeO}_{2}$ catalysts synthesized by one-step polymerization method. Applied Catalysis A General. 2014;483:52-62.

[143] Dan M, Mihet M, Tasnadi-Asztalos Z, Imre-Lucaci A, Katona G, Lazar MD. Hydrogen production by ethanol steam reforming on nickel catalysts: Effect of support modification by $\mathrm{CeO}_{2}$ and $\mathrm{La}_{2} \mathrm{O}_{3}$. Fuel. 2015;147:260-8.

[144] Qiu S, Gong L, Liu L, Hong C, Yuan L, Li Q. Hydrogen Production by Low-temperature Steam Reforming of Bio-oil over Ni/HZSM-5 Catalyst. Chinese Journal of Chemical Physics. 2011;24:211.

[145] Buchireddy PR, Bricka RM, Rodriguez J, Holmes W. Biomass gasification: catalytic removal of tars over zeolites and nickel supported zeolites. Energy \& Fuels. 2010;24:2707-15.

[146] Oemar U, Kathiraser Y, Ang ML, Hidajat K, Kawi S. Catalytic biomass gasification to syngas over highly dispersed lanthanum - doped nickel on SBA - 15. Chemcatchem. 2015;7:3376-85.

[147] Michel R, Łamacz A, Krzton A, Djéga-Mariadassou G, Burg P, Courson C, et al. Steam reforming of $\alpha$-methylnaphthalene as a model tar compound over olivine and olivine supported nickel. Fuel. 2013;109:653-60.

[148] García-García I, Acha E, Bizkarra K, Ilarduya JMD, Requies J, Cambra JF. Hydrogen production by steam reforming of $\mathrm{m}$-cresol, a bio-oil model compound, using catalysts supported on conventional and unconventional supports. International Journal of Hydrogen Energy. 2015;40:14445-55.

[149] Sarığlan A. Tar removal on dolomite and steam reforming catalyst: Benzene, toluene and xylene reforming. International Journal of Hydrogen Energy. 2012;37:8133-42.

[150] Sisinni M, Carlo AD, Bocci E, Micangeli A, Naso V. Hydrogen-rich gas production by sorption enhanced steam reforming of woodgas containing tar over a commercial $\mathrm{Ni}$ catalyst and calcined dolomite as CO2 sorbent. Energies. 2013;6:3167-81.

[151] Yang X, Xu S, Xu H, Liu X, Liu C. Nickel supported on modified olivine catalysts for steam reforming of biomass gasification tar. Catalysis Communications. 2010;11:383-6.

[152] Moura JS, Souza MOG, Bellido JDA, Assaf EM, Opportus M, Reyes P, et al. Ethanol steam reforming over rhodium and cobalt-based catalysts: Effect of the support. International Journal of Hydrogen Energy. 2012;37:3213-24.

[153] Li D, Zeng L, Li X, Wang X, Ma H, Assabumrungrat S, et al. Ceria-promoted Ni/SBA-15 catalysts for ethanol steam reforming with enhanced activity and resistance to deactivation. Applied Catalysis B Environmental. 2015;176-177:532-41.

[154] Constantinou DA, Fierro JLG, Efstathiou AM. A comparative study of the steam reforming of phenol towards $\mathrm{H}_{2}$ production over natural calcite, dolomite and olivine materials. Applied Catalysis B Environmental. 2010;95:255-69.

[155] Siedlecki M, Nieuwstraten R, Simeone E, Jong WD, Verkooijen AHM. Effect of magnesite as bed material in a $100 \mathrm{kWth}$ steam-oxygen blown circulating fluidized-bed biomass gasifier on gas composition and tar formation. Energy \& Fuels. 2009;23:5643-54.

[156] Chang CC, Chang LS, Tsai CY, Chan YC. Steam reforming of gasification-derived tar for syngas production. International Journal of Hydrogen Energy. 2014;39:19376-81.

[157] Wang G, Xu S, Jiang L, Wang C. Nickel supported on iron-bearing olivine for $\mathrm{CO}_{2}$ methanation. International Journal of Hydrogen Energy. 2016;41:12910-9.

[158] Wang G, Xu S, Wang C, Zhang J, Fang Z. Desulfurization and tar reforming of biogenous syngas 
over Ni/olivine in a decoupled dual loop gasifier. International Journal of Hydrogen Energy. 2017.

[159] König CFJ, Schildhauer TJ, Nachtegaal M. Methane synthesis and sulfur removal over a Ru catalyst probed in situ with high sensitivity X-ray absorption spectroscopy. Journal of Catalysis. 2013;305:92-100.

[160] Świerczyński D, Libs S, Courson C, Kiennemann A. Steam reforming of tar from a biomass gasification process over Ni/olivine catalyst using toluene as a model compound. Applied Catalysis B Environmental. 2007;74:211-22.

[161] Ye M, Tao Y, Jin F, Ling H, Wu C, Williams PT, et al. Enhancing hydrogen production from the pyrolysis-gasification of biomass by size-confined Ni catalysts on acidic MCM-41 supports. Catalysis Today. 2017.

[162] Wu C, Dong L, Onwudili J, Williams PT, Huang J. Effect of Ni particle location within the mesoporous MCM-41 support for hydrogen production from the catalytic gasification of biomass. Acs Sustainable Chemistry \& Engineering. 2013;1:1083-91.

[163] Soongprasit K, Aht-Ong D, Sricharoenchaikul V, Atong D. Synthesis and catalytic activity of sol-gel derived La-Ce-Ni perovskite mixed oxide on steam reforming of toluene. Current Applied Physics. 2012;12:S80-S8.

[164] Oemar U, Ang PS, Hidajat K, Kawi S. Promotional effect of Fe on perovskite $\mathrm{LaNi}_{\mathrm{x}} \mathrm{Fe}_{1-\mathrm{x}} \mathrm{O}_{3}$ catalyst for hydrogen production via steam reforming of toluene. International Journal of Hydrogen Energy. 2013;38:5525-34.

[165] Basagiannis AC, Verykios XE. Influence of the carrier on steam reforming of acetic acid over Ru-based catalysts. Applied Catalysis B Environmental. 2008;82:77-88.

[166] Dong L, Wu C, Ling H, Shi J, Williams PT, Huang J. Development of Fe-promoted Ni-Al catalyst for hydrogen production from gasification of wood sawdust. Energy \& Fuels. 2016;31:2118-27.

[167] Ashok J, Kawi S. Steam reforming of biomass tar model compound at relatively low steam-to-carbon condition over CaO-doped nickel-iron alloy supported over iron-alumina catalysts. Applied Catalysis A General. 2015;490:24-35.

[168] Koike M, Ishikawa C, Li D, Wang L, Nakagawa Y, Tomishige K. Catalytic performance of manganese-promoted nickel catalysts for the steam reforming of tar from biomass pyrolysis to synthesis gas. Fuel. 2013;103:122-9.

[169] Dagle VL, Dagle R, Kovarik L, Genc A, Wang YG, Bowden M, et al. Steam reforming of hydrocarbons from biomass-derived syngas over $\mathrm{MgAl}_{2} \mathrm{O}_{4}$-supported transition metals and bimetallic IrNi catalysts. Applied Catalysis B Environmental. 2016;184:142-52.

[170] Xie C, Chen Y, Engelhard MH, Song C. Comparative study on the sulfur tolerance and carbon resistance of supported noble metal catalysts in steam reforming of liquid hydrocarbon fuel. Acs Catalysis. 2012;2:1127-37.

[171] Guggilla VS, Akyurtlu J, Akyurtlu A, Blankson I. Steam reforming of n-Dodecane over $\mathrm{Ru}$-Ni-based catalysts. Industrial \& Engineering Chemistry Research. 2010;49:8164-73.

[172] Profeti LPR, Dias JAC, Assaf JM, Assaf EM. Hydrogen production by steam reforming of ethanol over Ni-based catalysts promoted with noble metals. Journal of Power Sources. 2009;190:525-33.

[173] Profeti LPR, Ticianelli EA, Assaf EM. Production of hydrogen via steam reforming of biofuels on $\mathrm{Ni} / \mathrm{CeO}_{2}-\mathrm{Al}_{2} \mathrm{O}_{3}$ catalysts promoted by noble metals. International Journal of Hydrogen Energy. 2009;34:5049-60. 
[174] Guo Y, Zhou L, Kameyama H. Steam reforming reactions over a metal-monolithic anodic alumina-supported $\mathrm{Ni}$ catalyst with trace amounts of noble metal. International Journal of Hydrogen Energy. 2011;36:5321-33.

[175] Jin N, Nakamura K, Asadullah M, Miyazawa T, Kunimori K, Tomishige K. Catalytic performance of $\mathrm{Ni} / \mathrm{CeO}_{2} / \mathrm{Al}_{2} \mathrm{O}_{3}$ modified with noble metals in steam gasification of biomass. Catalysis Today. 2008;131:146-55.

[176] Morales-Cano F, Lundegaard LF, Tiruvalam RR, Falsig H, Skjøth-Rasmussen MS. Improving the sintering resistance of $\mathrm{Ni} / \mathrm{Al}_{2} \mathrm{O}_{3}$ steam-reforming catalysts by promotion with noble metals. Applied Catalysis A General. 2015;498:117-25.

[177] Mei D, Glezakou VA, Lebarbier V, Kovarik L, Wan H, Albrecht KO, et al. Highly active and stable $\mathrm{MgAl}_{2} \mathrm{O}_{4}$-supported $\mathrm{Rh}$ and Ir catalysts for methane steam reforming: A combined experimental and theoretical study. Journal of Catalysis. 2014;316:11-23.

[178] Harshini D, Lee DH, Jeong J, Kim Y, Nam SW, Ham HC, et al. Enhanced oxygen storage capacity of $\mathrm{Ce}_{0.65} \mathrm{Hf}_{0.2} 5 \mathrm{M}_{0.1} \mathrm{O}_{2-\delta}(\mathrm{M}=$ rare earth elements): Applications to methane steam reforming with high coking resistance. Applied Catalysis B Environmental. 2014;148-149:415-23.

[179] Muñoz M, Moreno S, Molina R. Promoter effect of Ce and Pr on the catalytic stability of the Ni-Co system for the oxidative steam reforming of ethanol. Applied Catalysis A General. 2016;526:84-94.

[180] Laobuthee A, Veranitisagul C, Wattanathana W, Koonsaeng N, Laosiripojana N. Activity of Fe supported by $\mathrm{Ce}_{1-\mathrm{x}} \mathrm{Sm}_{\mathrm{x}} \mathrm{O}_{2-\delta}$ derived from metal complex decomposition toward the steam reforming of toluene as biomass tar model compound. Renewable Energy. 2015;74:133-8.

[181] Li R, Roy A, Bridges J, Dooley KM. Tar reforming in model gasifier effluents: Transition metal/rare earth oxide catalysts. Industrial \& Engineering Chemistry Research. 2014;53:7999-8011.

[182] Cheng H, Lu X, Zhang Y, Ding W. Hydrogen production by reforming of simulated hot coke oven gas over nickel catalysts promoted with lanthanum and cerium in a membrane reactor. Energy \& Fuels. 2009;23:3119-25.

[183] Zhang Y, Cheng H, Xionggang LU, Ding W, Zhou G. Influence of rare earth promoters on the performance of $\mathrm{Ni} / \mathrm{Mg}(\mathrm{Al}) \mathrm{O}$ catalysts for hydrogenation and steam reforming of toluene. Rare metals. 2009;28:582-9.

[184] Muñoz M, Moreno S, Molina R. Synthesis of Ce and Pr-promoted Ni and Co catalysts from hydrotalcite type precursors by reconstruction method. International Journal of Hydrogen Energy. 2012;37:18827-42.

[185] Muñoz M, Moreno S, Molina R. Promoting effect of Ce and Pr in Co catalysts for hydrogen production via oxidative steam reforming of ethanol. Catalysis Today. 2013;213:33-41.

[186] Zhang X, Fang X, Feng X, Li X, Liu W, Xu X, et al. Ni/ $\mathrm{Ln}_{2} \mathrm{Zr}_{2} \mathrm{O}_{7}$ ( $\mathrm{Ln}=\mathrm{La}, \mathrm{Pr}, \mathrm{Sm}$ and Y) catalysts for methane steam reforming: on the effects of A site replacement. Catalysis Science \& Technology. 2017.

[187] Zhang RQ, Wang YC, Brown RC. Steam reforming of tar compounds over Ni/olivine catalysts doped with $\mathrm{CeO}_{2}$. Energy Conversion \& Management. 2007;48:68-77.

[188] Tao J, Zhao LQ, Dong CQ, Qiang L, Du XZ, Dahlquist E. Catalytic steam reforming of toluene as a model compound of biomass gasification tar using $\mathrm{Ni}-\mathrm{CeO}_{2} / \mathrm{SBA}-15$ catalysts. Energies. 2013;6:3284-96.

[189] Zhang R, Wang H, Hou X. Catalytic reforming of toluene as tar model compound: Effect of Ce and Ce-Mg promoter using Ni/olivine catalyst. Chemosphere. 2014;97:40-6. 
[190] Ashok J, Kawi S. Steam reforming of toluene as a biomass tar model compoundover $\mathrm{CeO}_{2}$ promoted $\mathrm{Ni} / \mathrm{CaO}-\mathrm{Al}_{2} \mathrm{O}_{3}$ catalytic systems. International Journal of Hydrogen Energy. 2013;38:13938-49.

[191] Gonzalez-DelaCruz VM, Holgado JP, Pereñíguez R, Caballero A. Morphology changes induced by strong metal-support interaction on a Ni-ceria catalytic system. Journal of Catalysis. 2008;2:307-14.

[192] Kim DK, Stöwe K, Müller F, Maier WF. Mechanistic study of the unusual catalytic properties of a new NiCe mixed oxide for the $\mathrm{CO}_{2}$ reforming of methane. Journal of Catalysis. 2007;247:101-11.

[193] Kumar P, Sun Y, Idem RO. Nickel-based ceria, zirconia, and ceria-zirconia catalytic systems for low-temperature carbon dioxide reforming of methane. Energy \& Fuels. 2010;21:3113-23.

[194] Laobuthee A, Veranitisagul C, Wattanathana W, Koonsaeng N, Laosiripojana N. Activity of Fe supported by $\mathrm{Ce}_{1-\mathrm{x}} \mathrm{Sm}_{\mathrm{x}} \mathrm{O}_{2-\delta}$ derived from metal complex decomposition toward the steam reforming of toluene as biomass tar model compound. Renewable Energy. 2015;74:133-8.

[195] Pereñíguez R, González-Delacruz VM, Holgado JP, Caballero A. Synthesis and characterization of a $\mathrm{LaNiO}_{3}$ perovskite as precursor for methane reforming reactions catalysts. Applied Catalysis B Environmental. 2010;93:346-53.

[196] Frusteri F, Italiano G, Espro C, Cannilla C, Bonura G. $\mathrm{H}_{2}$ production by methane decomposition: Catalytic and technological aspects. International Journal of Hydrogen Energy. 2012;37:16367-74.

[197] Chen F, Wu C, Dong L, Vassallo A, Williams PT, Huang J. Characteristics and catalytic properties of $\mathrm{Ni} / \mathrm{CaAlO}_{\mathrm{x}}$ catalyst for hydrogen-enriched syngas production from pyrolysis-steam reforming of biomass sawdust. Applied Catalysis B Environmental. 2016;183:168-75.

[198] Dieuzeide ML, Laborde M, Amadeo N, Cannilla C, Bonura G, Frusteri F. Hydrogen production by glycerol steam reforming: How $\mathrm{Mg}$ doping affects the catalytic behaviour of $\mathrm{Ni} / \mathrm{Al}_{2} \mathrm{O}_{3}$ catalysts. International Journal of Hydrogen Energy. 2016;41:157-66.

[199] Song JH, Han SJ, Yoo J, Park S, Kim DH, Song IK. Effect of Sr content on hydrogen production by steam reforming of ethanol over Ni-Sr/ $\mathrm{Al}_{2} \mathrm{O}_{3}-\mathrm{ZrO}_{2}$ xerogel catalysts. Journal of Molecular Catalysis A Chemical. 2016;s 418-419:68-77.

[200] Sekine Y, Mukai D, Murai Y, Tochiya S, Izutsu Y, Sekiguchi K, et al. Steam reforming of toluene over perovskite-supported Ni catalysts. Applied Catalysis A General. 2013;451:160-7.

[201] Mukai D, Murai Y, Higo T, Tochiya S, Hashimoto T, Sugiura Y, et al. In situ IR study for elucidating reaction mechanism of toluene steam reforming over $\mathrm{Ni} / \mathrm{La}_{0.7} \mathrm{Sr}_{0.3} \mathrm{AlO}_{3-\delta}$ catalyst. Applied Catalysis A General. 2013;466:190-7.

[202] Mukai D, Tochiya S, Murai Y, Imori M, Hashimoto T, Sugiura Y, et al. Role of support lattice oxygen on steam reforming of toluene for hydrogen production over $\mathrm{Ni} / \mathrm{La}_{0.7} \mathrm{Sr}_{0.3} \mathrm{AlO}_{3-\delta}$ catalyst. Applied Catalysis A General. 2013;453:60-70.

[203] Takise K, Imori M, Mukai D, Ogo S, Sugiura Y, Sekine Y. Effect of catalyst structure on steam reforming of toluene over Ni/La ${ }_{0.7} \mathrm{Sr}_{0.3} \mathrm{AlO}_{3-\delta}$ catalyst. Applied Catalysis A General. 2015;489:155-61.

[204] Oemar U, Ang ML, Hee WF, Hidajat K, Kawi S. Perovskite $\mathrm{La}_{\mathrm{x}} \mathrm{M}_{1-\mathrm{x}} \mathrm{Ni}_{0.8} \mathrm{Fe}_{0.2} \mathrm{O}_{3}$ catalyst for steam reforming of toluene: Crucial role of alkaline earth metal at low steam condition. Applied Catalysis B Environmental. 2014;s 148-149:231-42.

[205] Keown DM, Hayashi JI, Li CZ. Effects of volatile-char interactions on the volatilisation of alkali and alkaline earth metallic species during the pyrolysis of biomass. Fuel. 2008;87:1187-94.

[206] Guan G, Kaewpanha M, Hao X, Wang Z, Cheng Y, Kasai Y, et al. Promoting effect of potassium addition to calcined scallop shell supported catalysts for the decomposition of tar derived from different 
biomass resources. Fuel. 2013;109:241-7.

[207] Erbel C, Mayerhofer M, Monkhouse P, Gaderer M, Spliethoff H. Continuous in situ measurements of alkali species in the gasification of biomass. Proceedings of the Combustion Institute. 2013;34:2331-8.

[208] Fatehi H, He Y, Wang Z, Li ZS, Bai XS, Aldén M, et al. LIBS measurements and numerical studies of potassium release during biomass gasification. Proceedings of the Combustion Institute. 2015;35:2389-96.

[209] Iwasa N, Yamane T, Arai M. Influence of alkali metal modification and reaction conditions on the catalytic activity and stability of $\mathrm{Ni}$ containing smectite-type material for steam reforming of acetic acid. International Journal of Hydrogen Energy. 2011;36:5904-11.

[210] Akiyama M, Oki Y, Nagai M. Steam reforming of ethanol over carburized alkali-doped nickel on zirconia and various supports for hydrogen production. Catalysis Today. 2012;181:4-13.

[211] Guan G, Kaewpanha M, Hao X, Zhu AM, Kasai Y, Kakuta S, et al. Steam reforming of tar derived from lignin over pompom-like potassium-promoted iron-based catalysts formed on calcined scallop shell. Bioresource Technology. 2013;139:280-4.

[212] Krerkkaiwan S, Mueangta S, Thammarat P, Jaisat L, Kuchonthara P. Catalytic biomass-derived tar decomposition using char from the co-pyrolysis of coal and giant leucaena wood biomass. Energy \& Fuels. 2015;29:150422152253000.

[213] Krerkkaiwan S, Fushimi C, Tsutsumi A, Kuchonthara P. Synergetic effect during co-pyrolysis/gasification of biomass and sub-bituminous coal. Fuel Processing Technology. 2013;115:11-8.

[214] Eom IY, Kim JY, Kim TS, Lee SM, Choi D, Choi IG, et al. Effect of essential inorganic metals on primary thermal degradation of lignocellulosic biomass. Bioresource Technology. 2012;104:687-94.

[215] Wang Z, Wang F, Cao J, Wang J. Pyrolysis of pine wood in a slowly heating fixed-bed reactor: Potassium carbonate versus calcium hydroxide as a catalyst. Fuel Processing Technology. 2010;91:942-50.

[216] Albertazzi S, Basile F, Brandin J, Einvall J, Fornasari G, Hulteberg C, et al. Effect of fly ash and HS on a Ni-based catalyst for the upgrading of a biomass-generated gas. Biomass \& Bioenergy. 2008;32:345-53.

[217] Li YP, Wang TJ, Wu CZ, Gao Y, Zhang XH, Wang CG, et al. Effect of alkali vapor exposure on $\mathrm{Ni}-\mathrm{MgO} / \gamma-\mathrm{Al}_{2} \mathrm{O}_{3} /$ cordierite monolithic catalyst for biomass fuel gas reforming. Industrial \& Engineering Chemistry Research. 2010;49:3176-83.

[218] Moud PH, Andersson KJ, Lanza R, Pettersson JBC, Engvall K. Effect of gas phase alkali species on tar reforming catalyst performance: Initial characterization and method development. Fuel. 2015;154:95-106. 


\section{Figure captions}

Figure 1. Structure of world primary energy consumption in 1990.

Figure 2. Main processes and reactions during biomass gasification.

Figure 3. Pathway of biomass gasification.

Figure 4. Proposed mechanism of primary, secondary, and tertiary tar formation.

Figure 5. (a) Effect of $\mathrm{Ni}$ precursors on catalytic performances of $\mathrm{Ni} / \mathrm{Al}_{2} \mathrm{O}_{3}$ catalysts in steam reforming of bio-derived glycerol for hydrogen production, (b) $\mathrm{H}_{2}$ molar yield and (c) TG profile for different $\mathrm{Ni} / \mathrm{Al}_{2} \mathrm{O}_{3}$ catalysts.

Figure 6. Schematic illustration of the better Ni dispersion for HMA@Ni/SBA-15 than for Ni/SBA-15 catalyst.

Figure 7. Schematic illustration of the Ni4/SBA-15 catalyst prepared by using a ligand-stabilized Ni4 cubane precursor.

Figure 8. SEM images of carbon deposition over used $\mathrm{Ni} / \mathrm{SiO}_{2}$ catalysts prepared by (a) sol-gel and (b) impregnation methods.

Figure 9. Images of scallop shells calcined at different temperatures. (a) Photographs; (b) SEM image of the surface of original scallop shell; (c) morphology of surface of scallop shell after calcined at $800{ }^{\circ} \mathrm{C}$.

Figure 10. XRD patterns of CS at different temperatures.

Figure 11. Schematic representation of catalytic process aspect of $\mathrm{Me}_{\mathrm{x}} \mathrm{O}_{\mathrm{y}} / \mathrm{CS}(\mathrm{Me}=\mathrm{Fe}$ or Ni) for the steam reforming of the tar derived from biomass.

Figure 12. The stability of used oxygen carriers (a) $\mathrm{Ni} / \mathrm{Al}_{2} \mathrm{O}_{3}$ (b) Ni/MMT (c) Ni/Al-MCM-41 (d) Ni/SBA-15.

Figure 13. Conversion and $\mathrm{H}_{2}$ yield (at initial time and after $18 \mathrm{~h}$ operation) from the catalytic cracking of naphthalene and toluene over catalysts with different supports at $700{ }^{\circ} \mathrm{C}$.

Figure 14. Results of the activity tests of non-catalyst, monometallic Ni catalyst and bimetallic Ni catalysts in the steam reforming $\left(\mathrm{ex}-\mathrm{O}_{2} / \mathrm{ex}-\mathrm{H}_{2} \mathrm{O} / \mathrm{C}=0 / 0.24 / 1\right)$ and oxidative steam reforming $\left(\mathrm{ex}-\mathrm{O}_{2} / \mathrm{ex}-\mathrm{H}_{2} \mathrm{O} / \mathrm{C}=0.09-0.24 / 0.24 / 1\right)$ of the biomass tar. Reaction conditions: biomass $60 \mathrm{mg} / \mathrm{min}$ $\left(\mathrm{H}_{2} \mathrm{O} 7.2 \%\right.$, C $\left.2356 \mu \mathrm{mol} / \mathrm{min}, \mathrm{H} 3325 \mu \mathrm{mol} / \mathrm{min}, \mathrm{O} 1454 \mu \mathrm{mol} / \mathrm{min}\right) ; \mathrm{ex}^{-} \mathrm{O}_{2} / \mathrm{ex}-\mathrm{H}_{2} \mathrm{O} / \mathrm{C}=(0,0.09,0.16$, or 0.24$) / 0.24 / 1 ; \mathrm{N}_{2} 60 \mathrm{ml} / \mathrm{min}$; reaction temperature $773 \mathrm{~K}$; reaction time $15 \mathrm{~min}$; catalyst: $\mathrm{Ni}-\mathrm{Fe}(\mathrm{Ni}-\mathrm{Fe} / \mathrm{Mg} / \mathrm{Al}(\mathrm{Fe} / \mathrm{Ni}=0.25)), \mathrm{Ni}-\mathrm{Cu}(\mathrm{Ni}-\mathrm{Cu} / \mathrm{Mg} / \mathrm{Al}(\mathrm{Cu} / \mathrm{Ni}=0.25))$, and noble metal-Ni catalysts (noble metal- $\mathrm{Ni} / \mathrm{Mg} / \mathrm{Al}$, noble metal $/ \mathrm{Ni}$ molar ratio $=0.0023$, which corresponds to $0.05 \mathrm{PdNi}$ in the case of $\mathrm{PdNi}$ ), weight $0.3 \mathrm{~g}$. Reduction conditions: $1073 \mathrm{~K}, \mathrm{H}_{2} / \mathrm{N}_{2}(30 / 30 \mathrm{ml} / \mathrm{min}), 30 \mathrm{~min}$.

Figure 15. (a) Simulated equilibrium structures of Ni50, Ir50 and Ir5Ni45 clusters on $\mathrm{MgAl}_{2} \mathrm{O}_{4}$ (111) support, and the corresponding distribution densities of metal atoms along the $\mathrm{Z}$ direction, (b) binding energies for the intermediates during methane dissociation $(\mathrm{KJ} / \mathrm{mol})$ over Ni50, Ir50, Ir25, and $\operatorname{Ir} 5 \mathrm{Ni} 45$ cluster model on spinel $\mathrm{MgAl}_{2} \mathrm{O}_{4}$ support (the energy for methane in the gas phase is selected as the reference), and (c) reaction energy profile for carbon monoxide formation via the route $\mathrm{O}+\mathrm{CH} \rightarrow$ $\mathrm{CHO}^{+} \rightarrow \mathrm{CO}+\mathrm{H}$ on selected Ir clusters and bulk (111) surface.

Figure 16. (a) Schematic drawing of mayenite (Each $\mathrm{AlO}_{4}$ is three dimensionally linked with one another by sharing corner oxygen atoms. 'Free' oxygen is located in micropores of mayenite), and (b) Raman spectra of mayenite and $\mathrm{Ni} /$ mayenite before reaction.

Figure 17. (a) XPS O 1s of reduced catalysts, and (b) carbon formation rate of spent catalysts for various alkaline earth metal addition. 
Figure 18. Conversion of acetic acid ( $\square$ ), selectivity of steam reforming ( $\square$ ) and $\mathrm{H}_{2}$ concentration (ש) in steam reforming of acetic acid over various alkali metal modified SM(Ni) materials at 1 min (a) and $200 \mathrm{~min}$ (b) from the start of the reaction. Reaction conditions: acetic acid $4.0 \%, \mathrm{H}_{2} \mathrm{O} 27 \%, \mathrm{~S} / \mathrm{C}$ ratio $=3.3$, temperature $723 \mathrm{~K}$.

Figure 19. Scheme of steam reforming of ethanol on $\mathrm{CsNi} / \mathrm{ZrO}_{2}$.

\section{Table captions}

Table 1. Global renewable energy scenario by 2040.

Table 2. Classification of tar based on molecular weight.

Table 3. Steam reforming of biomass tar over Ni-based catalysts.

Table 4. XRD and BET of the fresh Ce-Zr supported catalysts prepared using different methods.

Table 5. Classification of the support materials for preparation of steam reforming catalysts. 